\title{
Quality Assessment of Drinking Water in Tanta City,
}

\section{Egypt}

\author{
Maha Abdelfattah Khalil ${ }^{1}$, Zenhom El-Said Salem ${ }^{2}$, Saly Farouk Gheda ${ }^{1}$ and Moustafa Mohamed El-Sheekh ${ }^{1}$ \\ 1. Botany Department, Faculty of Science, Tanta University, Tanta 31527, Egypt \\ 2. Geology Department, Faculty of Science, Tanta University, Tanta 31527, Egypt
}

Received: February 22, 2013 / Accepted: April 29, 2013 / Pubslished: May 20, 2013.

\begin{abstract}
The physico-chemical and biological (algal and bacterial) quality of tap water in Tanta City were elucidated. Samples were collected during December 2011, covering all the water plants and the areal extension of the pipe line network in Tanta. Total dissolved solids content classifies water origin into surface water, shallow and deep groundwater. Fe, Mn and hardness in some samples of groundwater origin are obviously exceeding the WHO (World Health Organization) limit. Mostly, green algae are found (31 species), followed by diatoms (19 species), then blue-green algae (13 species). CCA (Canonical Corresponding Analysis) indicates that green algae are strongly correlated with $\mathrm{pH}, \mathrm{NH}_{4}$, alkalinity, $\mathrm{Mn}$ and $\mathrm{Si}$; diatoms with EC (electric conductivity), turbidity, Zn and Si and blue green algae with EC and alkalinity. 50\% of samples of surface origin, 80\% of samples of both deep and shallow groundwater origins crossed WHO and Egyptian guideline in their content of mean TCC (Total Coliform Count). CCA estimates strong correlations of TCC with temperature, $\mathrm{NH}_{4}$ and $\mathrm{PO}_{4}$; E. coli with EC; heterotrophic bacteria with turbidity and $\mathrm{NO}_{3}$; Salmonella sp. with $\mathrm{Si}$ and $\mathrm{SO}_{4}$ and Pseudomonas aeruginosa with Mn. Finally, the water plants treatment may be not effective and pipes serve as a reservoir for pathogenic microorganisms.
\end{abstract}

Key words: Water pollution, drinking water, physicochemical characteristics, algae, bacteria.

\section{Introduction}

Water is the most important thing for both human and the equilibrium of natural life. Every person needs approximately $2 \mathrm{~L}$ of clean drinking water pre day [1]. At the national level, domestic water use is $8 \%$ of total water use estimated at about 5.5 billion $\mathrm{m}^{3}$ per year. This corresponds to an average of about $200 \mathrm{~L}$ per capita per day (L/c/d). However, it varies considerably among different localities in Egypt. For example, the installed drinking water supply capacity ranges from 70 L/c/d in Upper Egypt to 330 L/c/d in Cairo.

The standards for drinking water can be attributed to two main criteria: (1) the absence of objectionable taste, odor and color; (2) the absence of substances with adverse physiological effects [2]. Therefore, water has to meet up with certain physical, chemical

Corresponding author: Zenhom El-Said Salem, Ph.D., associate professor, research fields: hydrogeology and environmental geology. E-mail: zenhomsalem@yahoo.com. and microbiological standards, that is, it must be free from diseases producing microorganisms and chemical substances, perilous to health before it can be termed potable [3].

The health concerns associated with chemical constituents of drinking-water differ from those associated with microbial contamination and arise primarily from the ability of chemical constituents to cause adverse health effects after prolonged periods of exposure. There are few chemical constituents of water that can lead to health problems resulting from a single exposure, except through massive accidental contamination of a drinking water supply. On the contrary, algal and bacterial contaminations are the most common and widespread health risk associated with drinking water [4]. In developing nations, more than 250 million new cases of waterborne diseases are reported annually. This has resulted in high morbidity and mortality rates, especially in young children [5]. 
Drinking water should contain no algae. Algae can affect water characteristics, such as alteration of organoleptic properties [6]. They produce mutagenic and carcinogenic substances which cause chronic effect on human physiology [7]. Certain cyanobacteria can produce toxins with pernicious health effects-diarrhea [8], to cite as an example, as an acute effect and cancer in the ultimate instance [9]. Whereas, diatoms generally produce obstructions in filters because of their silicon frustules [10]. The public health standards for safe drinking water for human consumption have the following bacterial guidelines: free from important index/indicator organisms including coliform bacteria (total coliforms, E. coli) and faecal streptococci/enterococci [11]. According to the WHO [12], E. coli is the parameter of choice for monitoring drinking water quality. Also, drinking water should not contain any bacteria indicative of fecal pollution such as Pseudomonas sp.. Heterotrophic bacterial count should not exceed 500 CFU (colony-forming unit) per mL [13].

Faecal contamination indicator bacteria have difficulties surviving in drinking waters when the concentrations of nutrients are carefully controlled [14]. Indeed, episodes of algal proliferation or heavy rainfall contribute to the temporary increase in specific organic compounds in untreated waters. High and low molecular weight extracellular algal compounds have been identified, including amino acids, peptides, fatty acids, carbohydrates, and vitamins [15].

Most components in water distribution networks may become excellent microbial environments. However, the persistence and proliferation of microorganisms in these systems are influenced by a number of factors [16]. Microorganisms, forming biofilms, colonize most of the exposed surfaces. Important categories of these organisms include bacteria [17]. In surface waters, algae occurring both in planktonic form and, as biofilms, may contain species which form toxins such as microcystin [18] and represent a serious threat to human beings.
This paper aims at determining the quality of tap water in Tanta City and relates the physicochemical and biological characteristics of tap water with standard guidelines for safe consumption or usage, aiming to estimate the efficiency of both treatment in water plants and the network of water pipes in Tanta. Tanta City is selected as it is the capital of Gharbyia governorate, the main target of the environmental strategic research plan of Tanta University, where authors affiliate.

\section{Materials and Methods}

\subsection{Sampling}

Twenty tap water samples were collected from Tanta City, during December, 2011. Sampling sites were chosen to cover all water plants and areal extension of the pipe line network in Tanta (Fig. 1). Samples were obtained directly from the taps after allowing the water to run for at least $5 \mathrm{~min}$.

\subsection{Physico-Chemical Analysis}

Drinking water samples were collected in prewashed clean polyethylene bottles. Temperature, $\mathrm{pH}$, TDS (Total Dissolved Solids) and conductivity of the samples were measured in site. Samples were subsequently stored at $4{ }^{\circ} \mathrm{C}$, for as short time as possible, before analysis to minimize physicochemical changes [19]. Because very little particulate matter was present in the sample, filtration was not considered necessary. Concentrations of alkalinity and chloride were measured by titration. Nitrate, nitrite, ammonia, sulfate and phosphate concentrations were determined by spectrophotometer. Turbidity level was examined by turbidometer. Cation concentration in acidified samples was measured using the ICP-AES (Inductively Coupled Plasma Atomic Emission Spectrometery) at the Institute of Desert Research, Cairo.

\subsection{Algae Analysis}

$1 \mathrm{~L}$ of each sample was preserved with Lugol's solution (iodine in potassium iodide) standard method [20] for the qualitative and quantitative investigation 


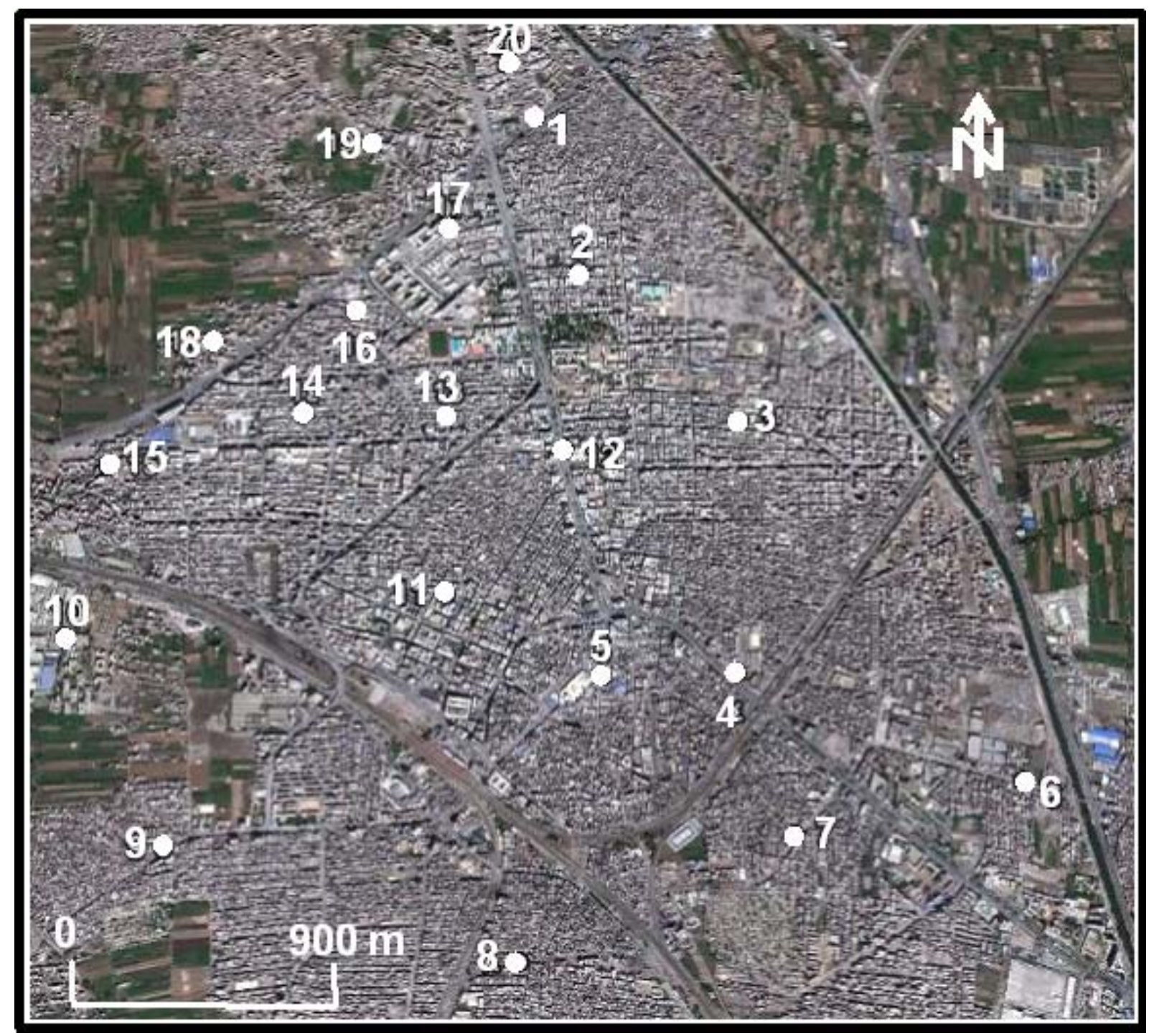

Fig. 1 Satellite image of Tanta City showing the sampling locations.

of phytoplankton. Identification of the algae was made according to Prescott [21], Whitford and Schumacher [22]. Counting of the phytoplankton population was made using a Sedgwick-Rafter counting chamber [23].

\subsection{Bacterial Analysis}

$500 \mathrm{~mL}$ samples were collected in plastic sterile bottles containing $0.25 \mathrm{~mL} \mathrm{Na}_{2} \mathrm{SO}_{3}$, whenever the water samples were chlorinated. Samples were taken from an inside faucet with the aerator removed, sterilized by flaming the end of the tap with disposable butane lighter. Samples were collected at the tap after running at full force for 5 min [24]. They were placed in a portable cooler $\left(4-8{ }^{\circ} \mathrm{C}\right)$ and transported to the laboratory, where they were analyzed within $24 \mathrm{~h}$ from sampling.

Examination of TC (Total Coliforms), heterotrophic bacteria, pathogenic bacteria (fecal streptococci, Salmonella sp., Pseudomonas aeurginosa, Escherichia coli and Staphylococcus aureus) were carried out for each sample in a duplicate manner using a membrane filtration technique [25]. Under aseptic conditions, $100 \mathrm{~mL}$ of drinking tap water sample was filtered through a gridded sterile cellulose-nitrate membrane filter $(0.45 \mu \mathrm{m}$ pore size, Sartorius type filters) under partial vacuum. The 
membrane filters were immediately removed with sterile forceps and placed on the following media with rolling motion to avoid entrapment of air: m-Endo agar for total coliform bacteria detection after $24 \mathrm{~h}$ at $35{ }^{\circ} \mathrm{C}$ [25], m-HPC (m-Heterotrphic plate count) agar for selective detection and enumeration of heterotrophic bacteria after $48 \mathrm{~h}$ at $35{ }^{\circ} \mathrm{C} . \mathrm{mE}$ (m-Enterococcus) agar and M-PA-C agar (BBL, MD) were used for detection and enumeration of Fecal streptococci and $P$. aeruginosa respectively, after $48 \mathrm{~h}$ at $35{ }^{\circ} \mathrm{C}$ and $72 \mathrm{~h}$ at $42.5^{\circ} \mathrm{C}$, respectively. Different agars were used for detection and enumeration of different bacteria. They include Mac Conkey agar [26, 27] for $E$. coli after $24 \mathrm{~h}$ at $45^{\circ} \mathrm{C}$, bismuth sulfite agar for Salmonella and manitol salt agar for Staphylococcus aureus (yellow colonies) at $37{ }^{\circ} \mathrm{C}$ for $24 \mathrm{~h}$. All colonies with different characteristics on cultured media were subcultured onto NA (nutrient agar) for purification. Isolated bacteria were identified on the basis of their colonial, morphological and biochemical properties following Bergey's Manual of Determinative Bacteriology [28].

\subsection{Statistical Analysis}

Two trends of multivariate analysis were applied to understand the similarities in phytoplankton composition between different samples. These trends are classification and ordination. The TWINSPAN (Two-Way Indicator Species Analysis) was used as a classification technique [29], while the DECORANA (DEtrended CORrespondence ANAlysis) was used as an ordination technique [30]. The data were statistically processed to estimate the mean \pm SD (Standard Deviation) of triplicates, and Pearson's correlation analysis was used to determine the relationships between the microbial indicators according to SPSS (Statistical Package for the Social Sciences) version 16.0 (SPSS Inc., Chicago, IL). A $P$ value of $<0.01$ was considered statistically significant. The matrix of biological (algal and bacterial) analyses and physicochemical characteristics of the investigated tap water samples were subjected to CCA (Canonical Corresponding Analysis) using CANOCO (CANonical Community Ordination) program [31].

\section{Results}

The physical and chemical properties of the drinking water samples from Tanta City were given in Table 1 and plotted in Fig. 2. Table 1 shows that TDS content is one of the water properties that are affected by the source of water. Samples were classified into three groups: Group 1 samples that may relate to surface water source $(1,2,3,4,5,8,9,10,11,17)$ of TDS < 300 ppm; Group 2 samples that may relate to shallow groundwater source $(13,16,18,19,20)$ of TDS > 400 ppm; and Group 3 samples that may relate to deep groundwater source $(6,7,12,14,15)$ of TDS $=300-400 \mathrm{ppm}$. Groundwater pumped from wells less than $70 \mathrm{~m}$ is considered shallow but that of deep more than $90 \mathrm{~m}$ is considered deep.

\subsection{Physico-Chemical Data}

The $\mathrm{pH}$ values were acceptable in the range of 7.35 to 7.7. All the samples have turbidity values (0.31-2.08) below WHO permissible value of 5 NTU. Electrical conductivity reached its minimum in Group $1\left(440 \mu \mathrm{s} \cdot \mathrm{cm}^{-1}\right)$ and its maximum in Group $2(1,420$ $\mu \mathrm{s} \cdot \mathrm{cm}^{-1}$ ). As shown in Fig. 2a, just three samples (13, 16 and 19) that belong to Group 2 have TDS values higher than WHO (2011) permissible limit. The values of alkalinity in all samples ranged from 134 $\mathrm{mg} \cdot \mathrm{L}^{-1}$ to $330 \mathrm{mg} \cdot \mathrm{L}^{-1}$ and were found comparable with the total hardness concentrations which ranged from $127.7 \mathrm{mg} \cdot \mathrm{L}^{-1}$ to $372 \mathrm{mg} \cdot \mathrm{L}^{-1}$. According to the common hardness scale, Group 1 water is moderately hard, and the other two groups ranged from hard to very hard. Because hardness above approximately $200 \mathrm{mg} \cdot \mathrm{L}^{-1}$ may cause scale deposition in the treatment works, distribution system, pipe work and tanks within buildings, therefore, Groups 2 and 3 waters are over the permissible limit (Fig. 2a). While the lowest level of the chloride in Group 1 is $34.8 \mathrm{mg} \cdot \mathrm{L}^{-1}$ (sample 8), 


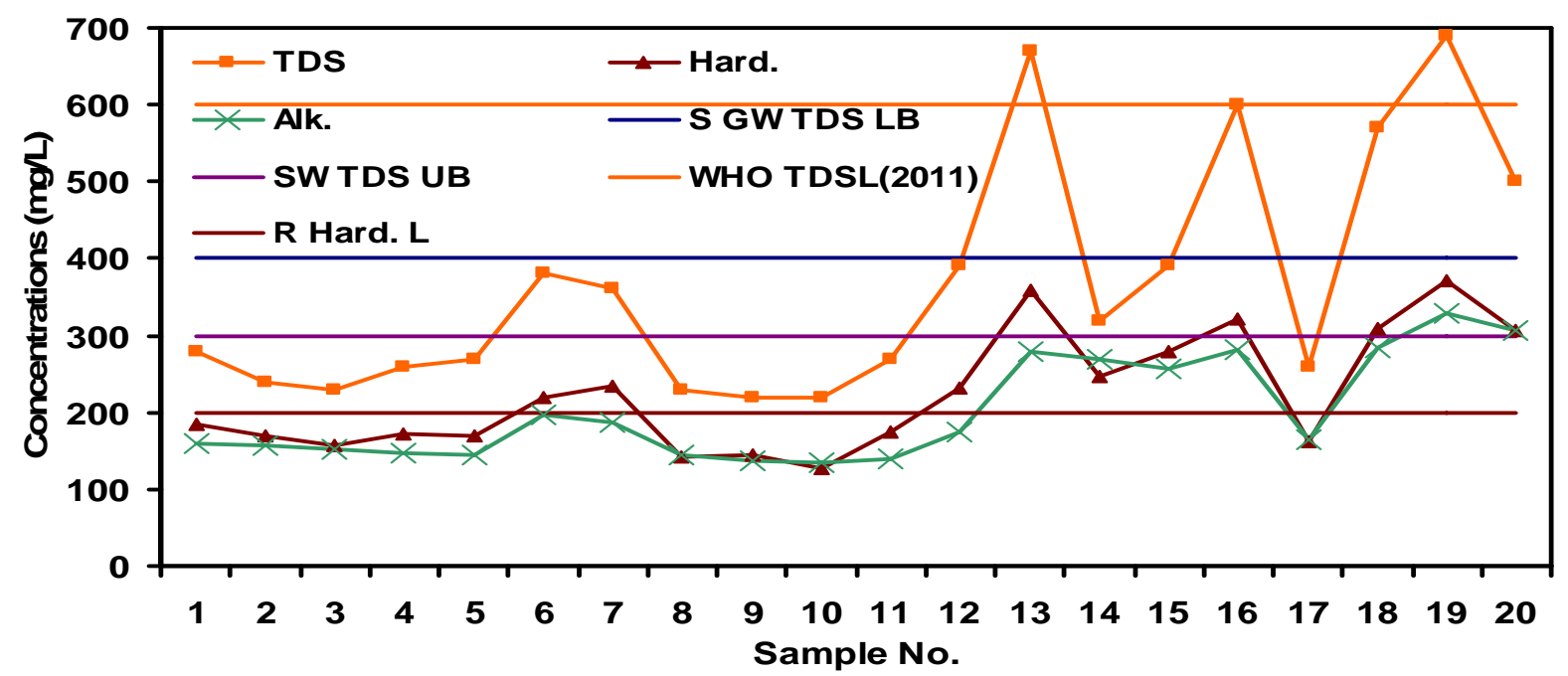

(a)

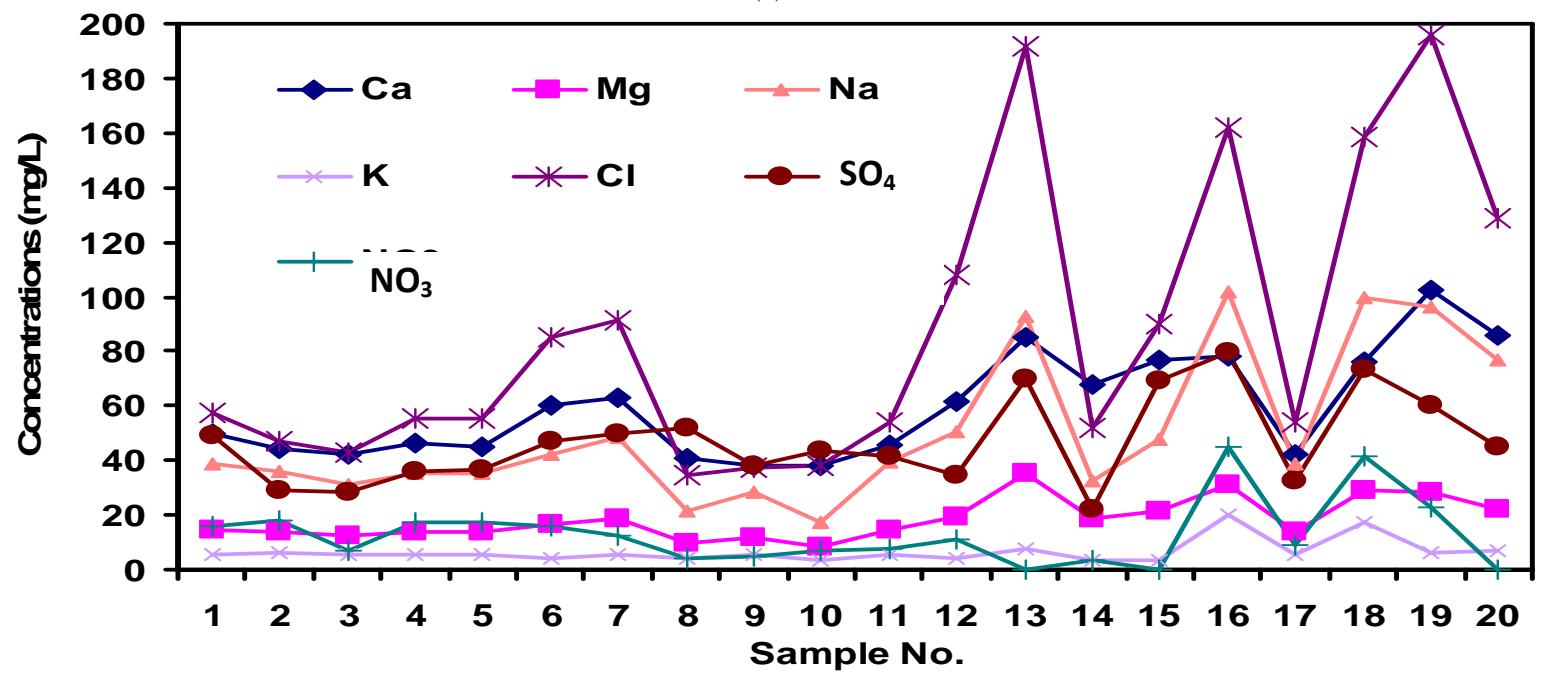

(b)

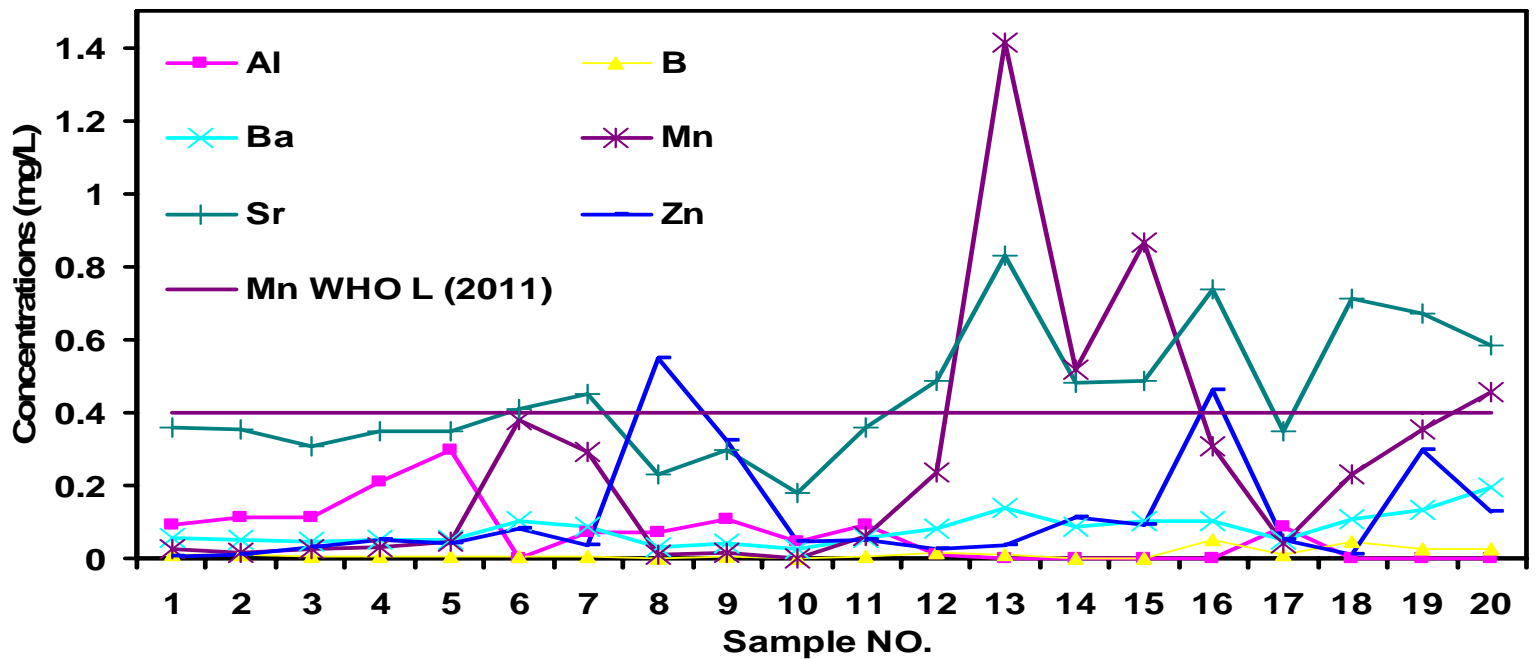

(c)

Fig. 2 Differences in the chemical composition of the analyzed samples. S GW TDS LB is the shallow groundwater TDS lower boundary; SW TDS UB is the surface water TDS upper boundary, and R Hard. $L$ is the recommended hardness limit. TDS of the deep groundwater ranged from SW TDS UB and S GW TDS LB. 
Table 1 Physico-chemical data of the analyzed water Samples.

\begin{tabular}{|c|c|c|c|c|c|c|c|c|c|c|c|c|c|c|c|c|c|}
\hline S. & & rb. & $\mathrm{H}$ & $\mathrm{C}$ & DS & rd. & K. & $\mathrm{a}$ & $\mathrm{Mg}$ & $\mathrm{Na}$ & $\mathrm{K}$ & $\mathrm{Cl}$ & 4 & $\mathrm{O}_{3}$ & 4 & $\mathrm{H}_{4}$ & $U_{2}$ \\
\hline 1 & 21.8 & 58 & 7 & 50 & 0 & .08 & 160 & 49.8 & 75 & 72 & 81 & 7.6 & 48.88 & 16.19 & 0.07 & 0 & 0 \\
\hline- & & & & 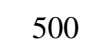 & 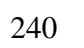 & & & & & & & .8 & 77 & .98 & 0.15 & 00 & 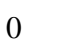 \\
\hline 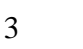 & & & & & 0 & & & & & & & & 28.28 & 7.14 & 0.32 & & 0 \\
\hline 4 & .4 & & & 30 & 60 & 3 & 146 & 46.1 & 1 & & & 5.2 & 36.07 & 17.1 & 32 & & 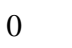 \\
\hline 5 & 3.6 & & & 0 & 0 & & 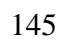 & 45.1 & & & & .2 & & & 8 & & 9 \\
\hline 6 & 0 & 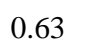 & & 0 & 380 & 219.42 & 150 & 60.5 & & & & 85.2 & 47.01 & 10.11 & 0.05 & - & 0.00 \\
\hline 7 & & & & 0 & 50 & 37 & 188 & 03 & 10.10 & & & .2 & 49.97 & 2.23 & 0.05 & & 01 \\
\hline 8 & .5 & 7 & & 450 & 230 & .28 & 144 & 40.8 & 811 & 21.61 & & 34.8 & 52.23 & 4.15 & 0.13 & .51 & 0 \\
\hline 9 & 21.8 & 8 & 7 & 0 & 20 & 5 & 136 & 7.9 & 1 & 8 & 3 & .2 & 4 & 84 & 18 & 75 & $0 \Leftrightarrow$ \\
\hline 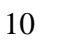 & 22.9 & & & & 220 & & 134 & 3 & & & & 4 & 43.29 & 2 & 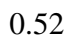 & 0.79 & 0 \\
\hline & & & & 0 & U & & 1 & 9 & 14.39 & & 5.386 & 54 & 41.29 & 1 & 9 & 6 & 18 \\
\hline 12 & 23.5 & 1 & & 0 & 390 & 59 & 174 & 61.3 & 19 & & 4.337 & 108 & 34.79 & 10.9 & 0.13 & 0 & 0.18 \\
\hline 13 & 20 & 050 & 7.7 & 120 & 670 & 358 & 280 & 85.3 & 35.28 & 92.91 & 7.422 & 192 & 69.98 & & 0.23 & - & 13 \\
\hline+ & 20.5 & & & & 0 & 246.56 & 268 & 67.9 & 18 & & 3.708 & 51.6 & 21.87 & 3.18 & 0.23 & 0.82 & 0.25 \\
\hline 15 & 24.3 & 0.34 & & & 390 & 2 & 256 & 76.7 & & 47.88 & 夏 & 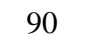 & 69.39 & 0 & 0.39 & 0.86 & 15 \\
\hline 16 & 22.6 & 0 & & 3 & 1 & 32 & 282 & 77.9 & 3 & 9 & 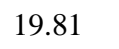 & 162 & 79.84 & 45.1 & 0.08 & 0 & 0.65 \\
\hline 17 & 22 & 0. & & & 0 & 37 & 164 & 42.3 & & & 98 & 54 & 32.62 & 9 & 0.01 & 0.02 & 0 \\
\hline 18 & 21.8 & & & & $5 / 0$ & 310.12 & 284 & 10 & & 99.65 & 17.51 & 158.4 & 73.23 & 41.2 & 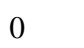 & 0.11 & 0.10 \\
\hline 19 & 21.0 & & & 40 & 90 & 372 & 330 & 103 & 28.17 & 96.08 & 6.412 & 195.6 & 60.02 & 22.5 & 0.04 & 0.01 & 0.14 \\
\hline 20 & 21.8 & 0.49 & 5 & 40 & 500 & 305.84 & 306 & 85.7 & 22.34 & 77.15 & 6.731 & 128.4 & 45.04 & 0 & 0.06 & 0.22 & 0.09 \\
\hline
\end{tabular}

Table 1 continued

\begin{tabular}{llllllllllll}
\hline S. No. & $\mathrm{Al}$ & $\mathrm{B}$ & $\mathrm{Ba}$ & $\mathrm{Bi}$ & $\mathrm{Cd}$ & $\mathrm{Co}$ & $\mathrm{Cr}$ & $\mathrm{Cu}$ & $\mathrm{Fe}$ & $\mathrm{Li}$ & $\mathrm{Mn}$ \\
\hline 1 & 0.0921 & 0.0089 & 0.0562 & $<0.002$ & $<0.0002$ & $<0.0004$ & $<0.004$ & $<0.001$ & $<0.006$ & 0.002 & 0.0247 \\
2 & 0.1135 & 0.0109 & 0.0514 & 0.0033 & $<0.0002$ & $<0.0004$ & $<0.004$ & $<0.001$ & $<0.006$ & 0.002 & 0.0177 \\
3 & 0.1122 & 0.0051 & 0.0481 & $<0.002$ & $<0.0002$ & $<0.0004$ & $<0.004$ & $<0.001$ & $<0.006$ & 0.001 & 0.0235 \\
4 & 0.2097 & 0.006 & 0.0523 & $<0.002$ & $<0.0002$ & $<0.0004$ & $<0.004$ & $<0.001$ & $<0.006$ & 0.002 & 0.0309 \\
5 & 0.2967 & 0.0052 & 0.053 & $<0.002$ & $<0.0002$ & $<0.0004$ & $<0.004$ & $<0.001$ & 0.0958 & 0.003 & 0.0476 \\
6 & $<0.006$ & 0.0043 & 0.1033 & $<0.002$ & $<0.0002$ & $<0.0004$ & $<0.004$ & $<0.001$ & 0.0632 & 0.001 & 0.3781 \\
7 & 0.0735 & 0.006 & 0.0867 & $<0.002$ & $<0.0002$ & $<0.0004$ & $<0.004$ & $<0.001$ & $<0.006$ & 0.002 & 0.2912 \\
8 & 0.0731 & $<0.002$ & 0.0299 & $<0.002$ & $<0.0002$ & $<0.0004$ & $<0.004$ & 0.002 & $<0.006$ & 0.002 & 0.0095 \\
9 & 0.1071 & 0.004 & 0.04 & $<0.002$ & $<0.0002$ & $<0.0004$ & $<0.004$ & $<0.001$ & $<0.006$ & 0.003 & 0.0154 \\
10 & 0.0464 & $<0.002$ & 0.0246 & $<0.002$ & $<0.0002$ & $<0.0004$ & $<0.004$ & 0.003 & $<0.006$ & 0.002 & 0.0014 \\
11 & 0.0928 & 0.0067 & 0.0542 & $<0.002$ & $<0.0002$ & $<0.0004$ & $<0.004$ & $<0.001$ & $<0.006$ & 0.002 & 0.061 \\
12 & 0.0085 & 0.0148 & 0.0816 & $<0.002$ & $<0.0002$ & $<0.0004$ & $<0.004$ & $<0.001$ & $<0.006$ & 0.002 & 0.2345 \\
13 & $<0.006$ & 0.0115 & 0.1381 & $<0.002$ & $<0.0002$ & 0.0005 & $<0.004$ & $<0.001$ & 0.0413 & 0.002 & 1.415 \\
14 & $<0.006$ & $<0.002$ & 0.0883 & $<0.002$ & $<0.0002$ & $<0.0004$ & $<0.004$ & $<0.001$ & 0.4426 & 0.001 & 0.5194 \\
15 & $<0.006$ & $<0.002$ & 0.103 & $<0.002$ & $<0.0002$ & $<0.0004$ & $<0.004$ & $<0.001$ & 0.1618 & 0.002 & 0.8634 \\
16 & $<0.006$ & 0.0536 & 0.1027 & $<0.002$ & $<0.0002$ & 0.0005 & $<0.004$ & 0.002 & $<0.006$ & 0.003 & 0.3065 \\
17 & 0.0857 & 0.009 & 0.0535 & $<0.002$ & $<0.0002$ & $<0.0004$ & $<0.004$ & $<0.001$ & $<0.006$ & 0.002 & 0.0387 \\
18 & $<0.006$ & 0.0478 & 0.106 & $<0.002$ & $<0.0002$ & $<0.0004$ & $<0.004$ & $<0.001$ & $<0.006$ & 0.002 & 0.2328 \\
19 & $<0.006$ & 0.0281 & 0.1344 & $<0.002$ & $<0.0002$ & $<0.0004$ & $<0.004$ & 0.005 & 0.0211 & 0.003 & 0.3529 \\
20 & $<0.006$ & 0.0235 & 0.1948 & $<0.002$ & $<0.0002$ & $<0.0004$ & $<0.004$ & $<0.001$ & 0.0258 & 0.002 & 0.4544 \\
\hline & & & & & & & & & & $<0$ \\
\hline
\end{tabular}


Table 1 continued

\begin{tabular}{llllllllllll}
\hline S. No. & Mo & $N i$ & $S$ & $S b$ & $S i$ & $S n$ & $S r$ & $T i$ & $V$ & $Z n$ & $M o$ \\
\hline 1 & $<0.0005$ & $<0.0007$ & $<0.002$ & $<0.004$ & 3.899 & $<0.001$ & 0.3607 & 0.008 & $<0.002$ & 0.003 & $<0.0005$ \\
2 & $<0.0005$ & $<0.0007$ & $<0.002$ & $<0.004$ & 3.096 & $<0.001$ & 0.3515 & 0.0082 & 0.0036 & 0.009 & $<0.0005$ \\
3 & 0.0006 & $<0.0007$ & $<0.002$ & $<0.004$ & 3.288 & $<0.001$ & 0.3076 & 0.0068 & 0.0035 & 0.032 & 0.0006 \\
4 & 0.0008 & $<0.0007$ & $<0.002$ & $<0.004$ & 2.385 & $<0.001$ & 0.3486 & 0.0083 & 0.0034 & 0.051 & 0.0008 \\
5 & $<0.0005$ & $<0.0007$ & $<0.002$ & $<0.004$ & 2.392 & $<0.001$ & 0.3476 & 0.0095 & 0.0039 & 0.039 & $<0.0005$ \\
6 & $<0.0005$ & $<0.0007$ & $<0.002$ & $<0.004$ & 13.13 & $<0.001$ & 0.4116 & 0.0097 & $<0.002$ & 0.08 & $<0.0005$ \\
7 & 0.0007 & $<0.0007$ & $<0.002$ & $<0.004$ & 5.435 & $<0.001$ & 0.4489 & 0.011 & $<0.002$ & 0.034 & 0.0007 \\
8 & 0.0008 & $<0.0007$ & $<0.002$ & $<0.004$ & 0.297 & 0.0031 & 0.2283 & 0.0062 & $<0.002$ & 0.547 & 0.0008 \\
9 & 0.0006 & $<0.0007$ & $<0.002$ & $<0.004$ & 0.255 & $<0.001$ & 0.2961 & 0.0074 & 0.0036 & 0.322 & 0.0006 \\
10 & 0.0012 & $<0.0007$ & $<0.002$ & $<0.004$ & 0.245 & 0.0027 & 0.1809 & 0.0045 & $<0.002$ & 0.045 & 0.0012 \\
11 & 0.0007 & $<0.0007$ & $<0.002$ & $<0.004$ & 4.333 & $<0.001$ & 0.3595 & 0.008 & 0.0041 & 0.049 & 0.0007 \\
12 & 0.0007 & $<0.0007$ & $<0.002$ & $<0.004$ & 12.78 & $<0.001$ & 0.4842 & 0.0106 & $<0.002$ & 0.025 & 0.0007 \\
13 & 0.0014 & $<0.0007$ & $<0.002$ & $<0.004$ & 13.82 & $<0.001$ & 0.8293 & 0.017 & 0.0042 & 0.035 & 0.0014 \\
14 & 0.0008 & $<0.0007$ & $<0.002$ & $<0.004$ & 13.41 & $<0.001$ & 0.481 & 0.0114 & $<0.002$ & 0.112 & 0.0008 \\
15 & 0.0008 & $<0.0007$ & $<0.002$ & $<0.004$ & 14.07 & $<0.001$ & 0.4863 & 0.012 & $<0.002$ & 0.094 & 0.0008 \\
16 & 0.0032 & $<0.0007$ & $<0.002$ & $<0.004$ & 11.79 & 0.002 & 0.7391 & 0.0133 & 0.0049 & 0.461 & 0.0032 \\
17 & 0.0009 & $<0.0007$ & $<0.002$ & $<0.004$ & 4.417 & $<0.001$ & 0.3484 & 0.0085 & 0.0041 & 0.052 & 0.0009 \\
18 & 0.0032 & $<0.0007$ & $<0.002$ & $<0.004$ & 11.54 & $<0.001$ & 0.7112 & 0.0132 & 0.0034 & 0.012 & 0.0032 \\
19 & 0.0013 & $<0.0007$ & $<0.002$ & $<0.004$ & 12.57 & $<0.001$ & 0.671 & 0.0152 & 0.0053 & 0.296 & 0.0013 \\
20 & 0.0011 & $<0.0007$ & $<0.002$ & $<0.004$ & 12.78 & $<0.001$ & 0.5826 & 0.0147 & $<0.002$ & 0.126 & 0.0011 \\
\hline
\end{tabular}

Note: Temperature in ${ }^{\circ} \mathrm{C}$, turbidity in unites, EC in $\mu \mathrm{S} / \mathrm{cm}$ and all concentrations of chemical elements in $\mathrm{mg} / \mathrm{L}$.

the highest level of the chloride $\left(195.6 \mathrm{mg} \cdot \mathrm{L}^{-1}\right)$ was found in the Group 2 (sample 19). Chloride concentration in all samples is below WHO permissible limits (Fig. 2b). Nitrate and nitrite in the investigated samples were found to be in a range of $0.0 \mathrm{mg} \cdot \mathrm{L}^{-1}$ to $57.41 \mathrm{mg} \cdot \mathrm{L}^{-1}$ and $0.0 \mathrm{mg} \cdot \mathrm{L}^{-1}$ to 0.65 $\mathrm{mg} \cdot \mathrm{L}^{-1}$, respectively. The range of sulphate $\left(\mathrm{SO}_{4}{ }^{2-}\right)$ in the samples was $21.87 \mathrm{mg} \cdot \mathrm{L}^{-1}$ to $79.84 \mathrm{mg} \cdot \mathrm{L}^{-1}$. Nitrate, nitrite and sulphate concentrations were below the WHO permissible limits (Table 1 and Fig. 2). Ammonia in drinking water is not of immediate health relevance, therefore, no health based guideline value is proposed. However, ammonia can compromise disinfection efficiency, result in nitrite formation in distribution systems, cause the failure of filters for the removal of manganese, and cause taste and odor problems. Ammonia varied from $0.0 \mathrm{mg} \cdot \mathrm{L}^{-1}$ to 0.86 $\mathrm{mg} \mathrm{L}^{-1}$ which is below WHO Standards $\left(1.5 \mathrm{mg} \cdot \mathrm{L}^{-1}\right)$.

Calcium and magnesium in the investigated water samples were found in the range of 37.75-102.6 $\mathrm{mg} \cdot \mathrm{L}^{-1}$ and 8.15-35.28 $\mathrm{mg} \cdot \mathrm{L}^{-1}$, respectively. This range is compatible with the legislation values for calcium and magnesium. No health-based guideline value is proposed for sodium and potassium. However, sodium concentrations in excess of $200 \mathrm{mg} \cdot \mathrm{L}^{-1}$ may give rise to unacceptable taste. Therefore, sodium and potassium concentrations in the analyzed samples (rang from $17.11 \mathrm{ppm}$ to $99.65 \mathrm{ppm}$ and from $3.5 \mathrm{ppm}$ to $19.81 \mathrm{ppm}$ respectively) are under the permissible limit (Fig. 2b).

Copper concentrations in the drinking water samples were under the detection limit except samples 8, 10, 16 and 19 where they have very low level (0.002-0.005 $\mathrm{mg} \cdot \mathrm{L}^{-1}$ ) (Table 1). Almost all the samples contain amount of iron lower than the detection limit except in samples 5, 6, 13, 15, 19 and 20 where it was below the acceptance WHO limit of which is $0.3 \mathrm{mg} \mathrm{L}^{-1}$, but sample 14 has higher level $\left(0.44 \mathrm{mg} \cdot \mathrm{L}^{-1}\right)$. Such low iron concentration in tap water compared to original groundwater and surface water is revered to the oxidation treatment process used in the pumping stations. The levels of zinc in the samples were in the range of $0.0033 \mathrm{mg} \cdot \mathrm{L}^{-1}$ to 0.55 $\mathrm{mg} \cdot \mathrm{L}^{-1}$. None of the drinking water samples analyzed 
for zinc exceeded the limit permitted by WHO but it generally shows groundwater origin. Average manganese levels were found to be in the range of $0.0014 \mathrm{mg} \cdot \mathrm{L}^{-1}$ to $1.45 \mathrm{mg} \cdot \mathrm{L}^{-1}$. Manganese content is higher than WHO limit in the water Group 2 samples pumped from the shallow groundwater (samples 13, 14, 15 and 20) and gets its lowest level in Group 2 samples of surface water origin (Fig. 2c). It means that the manganese oxidation treatment process in pumping stations is not effective for reducing its level. The direct relation between manganese and silicon concentrations, as shown in Fig. 3, indicates that such higher concentrations are related to the groundwater origin. Aluminum in the present water samples is related to surface input because its concentration was in the range from below the detection limit in water samples of groundwater origin to $0.296 \mathrm{mg} \cdot \mathrm{L}^{-1}$ in the samples of surface origin.

Nickel, antimony, tin, silver, bismuth, cadmium, cobalt and chromium are found below the detection limit in all the samples except few cases with no significance. The daily average intakes of silicon apparently range from about $20 \mathrm{mg} \cdot \mathrm{d}^{-1}$ to $50 \mathrm{mg} \cdot \mathrm{d}^{-1}$. Therefore, the present water is quite save for silicon where it reaches its lower concentration in the originally surface water samples $\left(0.244 \mathrm{mg} \cdot \mathrm{L}^{-1}\right)$ and its higher level in samples pumped from groundwater (14.07 $\mathrm{mg} \cdot \mathrm{L}^{-1}$ ) (Table 1). Strontium in the present samples behave in the same way as silicon depending on the water origin, where higher concentration recorded in sample $13\left(0.82 \mathrm{mg} \cdot \mathrm{L}^{-1}\right)$ and sample 10

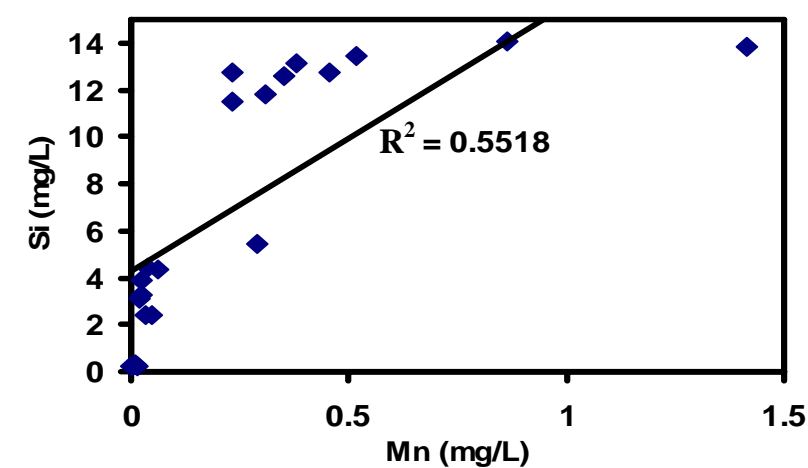

Fig. $3 \mathrm{Mn}(\mathrm{mg} / \mathrm{L})$ versus $\mathrm{Si}(\mathrm{mg} / \mathrm{L})$ in water samples of different water origins. has the lowest level $\left(0.18 \mathrm{mg} \cdot \mathrm{L}^{-1}\right)$. Barium and boron concentrations were lower than the WHO permissible limit in all the samples (Fig. 2c). The concentration level of lithium, molybdenum, titanium and vanadium are very low and sometimes below the detection limit in molybdenum and vanadium.

\subsection{Quantitative Estimation of Phytoplankton}

Microscopic quantitative analysis of phytoplankton in collected tap water showed that they belong to three main divisions: Chlorophyta (green algae), Cyanophyta (blue-green algae) and Bacillariophyta (diatoms). Table 2 lists the counting species of each division, with their abbreviations for further usage in statistical analysis. The most abundant phytoplanktons are the green algae (31 species), followed by diatoms (19 species), whereas blue green algae are present with lowest abundance (13 species). On the other hand, some examined samples are free from diatoms and others are free from blue green algae.

Algal Count

The green algae species count $\left(0.24 \times 10^{5}-3.24 \times\right.$ $10^{5}$ organisms $\cdot \mathrm{L}^{-1}$ ) is the highest among all samples of study (Figs. 4a, 4b and 4c), except of samples 1 and 2 (Group 1) and 16 (Group 2) where diatoms are the highest, and 19 (Group 2) where blue green algae are the highest. Diatoms and blue green algae have the same ranges of counts $\left(0.06 \times 10^{5}-1.44 \times 10^{5}\right.$ organisms $\cdot \mathrm{L}^{-1}$ ). Comparing sample groups, surface water related samples (Group 1) contain more green algae counts. Green algae are more abundant in surface related samples (Group 1) (Fig. 4a). The number of species of each algal division, on the other hand, does not usually show the same relation with the source of water. The maximum number of green algae species (10 species) was reported in shallow groundwater related samples (sample 13, Fig. 4b), while that of diatoms species (five species) was reported in surface water related samples (samples 2, 4 and 16), and that of blue green algae species (four species) was reported in surface water related samples (sample 17) (Table 2). 
Table 2 Variations in frequency of algal taxa in collected drinking water samples.

\begin{tabular}{|c|c|c|c|c|c|c|c|c|c|c|c|c|c|c|c|c|c|c|c|c|c|}
\hline Algal species & & S1 & $\mathrm{S} 2$ & S3 & $\mathrm{S} 4$ & S5 & S6 & S7 & S8 & S9 & S10 & S11 & S12 & $\mathrm{S} 13$ & $\mathrm{~S} 14$ & S15 & S16 & S17 & S18 & S19 & S20 \\
\hline \multicolumn{22}{|c|}{ Green algae } \\
\hline Actinastrum hantzschii & G1 & - & - & - & + & - & - & - & - & - & - & - & - & - & - & - & + & - & - & - & - \\
\hline Ankistrodesmus acicularis & $\mathrm{G} 2$ & - & - & - & - & - & ++ & - & ++ & ++++ & +++ & +++ & ++++ & - & - & +++ & - & ++++ & + & - & ++++ \\
\hline Ankistrodesmus angustus & G3 & - & - & - & - & - & - & - & & + & + & - & & + & - & - & - & - & - & - & - \\
\hline Ankistrodesmus spiralis & G4 & - & ++ & - & - & - & + & - & ++ & + & ++ & - & +++ & + & - & - & - & - & - & - & - \\
\hline Botryococcus braunii & G5 & - & - & - & - & + & + & + & - & - & - & - & - & + & & + & - & - & + & - & + \\
\hline Chodatella armata & G6 & - & - & - & - & - & - & - & - & - & - & - & + & - & - & - & - & - & - & - & - \\
\hline Closterium pronum & G8 & - & - & ++++ & ++ & - & ++ & ++ & ++++ & ++++ & ++++ & - & - & - & - & ++ & + & - & ++++ & - & - \\
\hline Coelastrum cubicum & G9 & - & - & - & - & + & - & - & - & - & - & - & - & - & - & - & - & - & - & - & - \\
\hline Coelastrum microporum & G10 & - & - & - & - & + & - & - & - & - & - & ++ & - & + & - & ++ & - & - & - & - & - \\
\hline Coelastrum reticulatum & G11 & - & - & - & - & - & ++ & ++ & ++ & ++ & - & - & ++ & - & - & - & - & - & - & + & ++ \\
\hline Coelastrum sphaericum & G12 & - & - & - & - & ++ & - & - & - & - & - & - & - & + & - & -- & - & - & - & - & - \\
\hline $\begin{array}{l}\text { Dictyosphaerium } \\
\text { ehrenbergianum }\end{array}$ & G13 & - & - & - & - & - & ++ & ++ & - & - & +++ & +++ & - & + & - & - & - & +++ & +++ & + & +++ \\
\hline Haematococcus pluvialis & G14 & - & - & - & - & - & - & - & - & - & - & - & - & - & - & - & - & +++ & - & + & - \\
\hline Kirchneriella gracillima & G16 & - & - & - & - & - & - & - & - & - & ++ & ++ & + & + & - & - & - & - & - & ++ & ++ \\
\hline Kirchneriella lunaris & G17 & - & - & + & - & - & - & - & - & ++ & - & - & - & + & + & ++ & - & - & - & - & - \\
\hline Kirchneriella obesa & G18 & - & - & - & - & + & + & + & - & - & - & - & - & - & - & - & - & - & - & ++ & ++ \\
\hline Mougeotia sp. & G19 & - & - & - & - & - & - & - & - & - & - & - & - & - & - & - & - & - & + & - & - \\
\hline Nephrocytium lunatum & G20 & - & - & - & - & - & - & - & - & - & - & - & - & - & - & - & + & + & - & + & - \\
\hline Oocystis parva & G21 & - & - & - & - & - & - & + & - & - & - & - & - & + & + & - & - & - & -- & + & + \\
\hline Pediastrum sturmii & G22 & + & + & - & - & - & - & - & - & - & - & - & - & - & - & - & - & - & - & - & - \\
\hline Scenedesmus acutus & G23 & + & & - & - & - & - & + & - & - & - & - & - & - & - & - & - & - & - & - & - \\
\hline Scenedesmus quadricauda & G24 & + & - & - & - & - & - & - & - & - & - & - & - & - & - & - & - & - & - & - & - \\
\hline Selenastrum gracile & G25 & - & - & - & - & - & - & - & - & - & - & - & - & + & - & + & - & - & - & - & - \\
\hline Spirogyra & G26 & - & + & ++ & + & - & - & - & - & - & - & - & + & - & - & + & + & - & - & - & - \\
\hline Staurastrum dejectum & G27 & - & - & - & + & - & - & - & - & - & - & - & - & - & - & - & - & - & - & - & - \\
\hline Tetradinium intermedium & G28 & - & ++ & - & - & - & - & - & - & - & - & - & - & - & - & - & - & - & - & - & - \\
\hline Tetraedron minimum & G29 & - & - & + & + & - & - & + & - & + & + & - & - & - & - & - & - & + & - & - & + \\
\hline Tetraedron muticum & G30 & - & - & - & - & + & - & - & - & - & - & - & + & - & - & - & + & - & - & - & + \\
\hline- & G31 & - & - & - & + & - & - & + & - & - & - & - & - & - & - & - & - & - & - & - & - \\
\hline
\end{tabular}


Table 2 continued

\begin{tabular}{|c|c|c|c|c|c|c|c|c|c|c|c|c|c|c|c|c|c|c|c|c|c|}
\hline Algal species & & S1 & S2 & S3 & $\mathrm{S} 4$ & S5 & S6 & S7 & S8 & S9 & $\mathrm{S} 10$ & $\mathrm{~S} 11$ & $\mathrm{~S} 12$ & $\mathrm{~S} 13$ & S14 & S15 & S16 & S17 & $\mathrm{S} 18$ & S19 & $\mathrm{S} 20$ \\
\hline \multicolumn{22}{|c|}{ Diatoms } \\
\hline Amphora ovalis & D1 & - & - & - & + & - & - & - & - & - & - & + & - & - & - & - & - & - & - & - & - \\
\hline Caloneis silicula & D2 & - & - & - & + & - & - & - & - & - & - & - & - & - & - & - & - & - & - & - & - \\
\hline Cocconeis placentula & D3 & - & - & - & - & + & - & - & - & - & - & - & - & - & - & - & - & - & - & - & + \\
\hline Cyclotella comta & D4 & - & - & - & - & - & - & - & - & - & - & - & - & - & - & - & ++ & - & - & - & - \\
\hline Cyclotella kutzingiana & D5 & ++ & - & ++ & ++ & + & - & + & + & - & - & - & - & - & + & - & - & + & - & - & + \\
\hline Diatoma elongatum & D6 & - & - & - & - & - & - & - & - & - & - & - & - & - & - & - & - & - & - & - & - \\
\hline Fragilaria capucina & D7 & - & - & - & - & - & - & - & - & - & - & - & - & - & - & - & ++ & - & - & - & - \\
\hline Fragilaria crotonensis & D8 & + & - & - & - & - & - & - & - & - & - & - & - & - & - & - & + & - & - & - & - \\
\hline Gomphonema olivaceum & D9 & - & - & - & - & + & - & - & - & - & - & - & - & + & - & - & - & - & - & - & - \\
\hline Navicula cryptocephaia & D10 & - & - & - & - & - & - & - & - & + & - & - & - & - & - & - & - & - & - & - & - \\
\hline Nitzchia acicularis & D11 & - & +++ & - & - & - & - & - & - & - & - & - & - & - & - & - & - & - & - & - & - \\
\hline Stephanodiscus astrea & D12 & & - & - & - & - & - & - & + & - & - & - & - & - & - & - & - & - & - & - & - \\
\hline Stephanodiscus hantzchii & $\mathrm{D} 13$ & - & - & + & + & - & - & - & - & - & - & - & - & - & - & - & + & - & - & - & - \\
\hline Surirella angustata & D14 & - & - & - & - & - & - & + & - & - & - & - & - & + & - & - & - & - & - & - & - \\
\hline Surirella ovata & D15 & - & - & - & - & - & - & - & - & - & - & - & - & - & + & - & + & - & - & - & - \\
\hline Surirella robusta & D16 & - & - & - & - & - & - & - & - & - & - & + & - & - & - & - & - & - & - & - & - \\
\hline Syndra acus & D17 & ++ & - & - & - & - & - & - & - & - & - & - & - & - & - & - & - & - & - & - & - \\
\hline Syndra ulna & D18 & ++ & +++ & - & ++ & +++ & + & ++ & - & - & - & + & - & - & - & - & - & - & - & - & - \\
\hline Syndra vaucheriae & D19 & - & + & - & - & - & - & - & - & - & - & - & - & - & - & - & - & - & - & - & - \\
\hline \multicolumn{22}{|l|}{ Blue green algae } \\
\hline Calothrix braunii & B1 & - & - & - & +++ & + & - & - & - & - & - & - & - & - & ++ & - & + & & - & - & - \\
\hline Chroococcus turgidus & B2 & - & - & + & - & + & - & + & - & - & - & + & - & - & - & - & - & + & - & - & - \\
\hline Dactylococcopsis acicularis & B3 & - & - & - & - & - & - & - & - & - & - & - & - & + & - & +++ & - & - & - & ++++ & - \\
\hline Dactylococcopsis fascicularis & B4 & - & - & - & - & - & - & - & - & - & ++ & - & - & + & - & - & - & ++ & - & + & - \\
\hline $\begin{array}{l}\text { Dactylococcopsis } \\
\text { rhaphidioides }\end{array}$ & B5 & - & - & - & - & - & - & - & - & - & - & - & - & + & ++ & - & - & - & - & - & - \\
\hline Gomphosphaeria lacustris & B6 & + & - & - & - & - & - & - & - & - & - & - & - & - & - & - & - & - & - & - & - \\
\hline Lyngbya martensiana & B7 & + & - & - & - & - & - & - & - & - & - & - & - & - & - & - & - & - & - & - & - \\
\hline Merismopedia elegans & B8 & - & - & - & - & - & - & - & - & - & - & - & - & - & - & - & - & + & - & - & - \\
\hline Merismopedia glauca & B9 & - & ++ & + & - & - & - & - & - & - & - & ++ & + & - & - & - & - & + & - & - & - \\
\hline Oscillatoria formosa & B10 & + & - & - & - & - & - & - & - & - & - & - & - & - & - & - & - & - & - & - & - \\
\hline Oscillatoria limnetica & B11 & - & - & - & - & - & - & - & - & - & - & - & - & - & - & ++ & - & - & - & - & - \\
\hline Rivularia blastotellana & B12 & - & + & - & - & - & - & - & - & - & - & - & - & - & - & + & - & - & - & - & - \\
\hline Spirulina abbreviata & B13 & - & - & - & - & + & - & - & - & - & - & + & - & - & - & - & - & - & - & - & - \\
\hline
\end{tabular}

$(-)$ absent, $(+)$ weakly present, $(++)$ moderately present, $(+++)$ strongly present, $(++++)$ very strongly present 


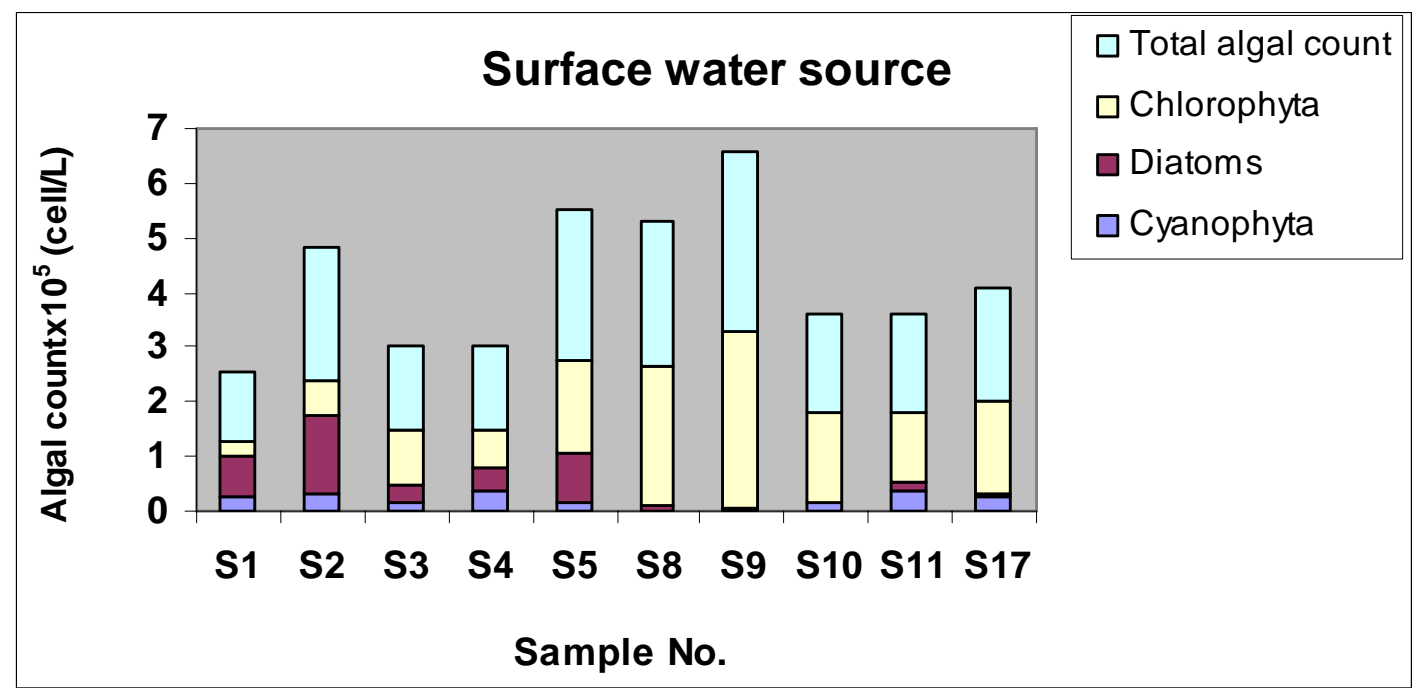

(a)

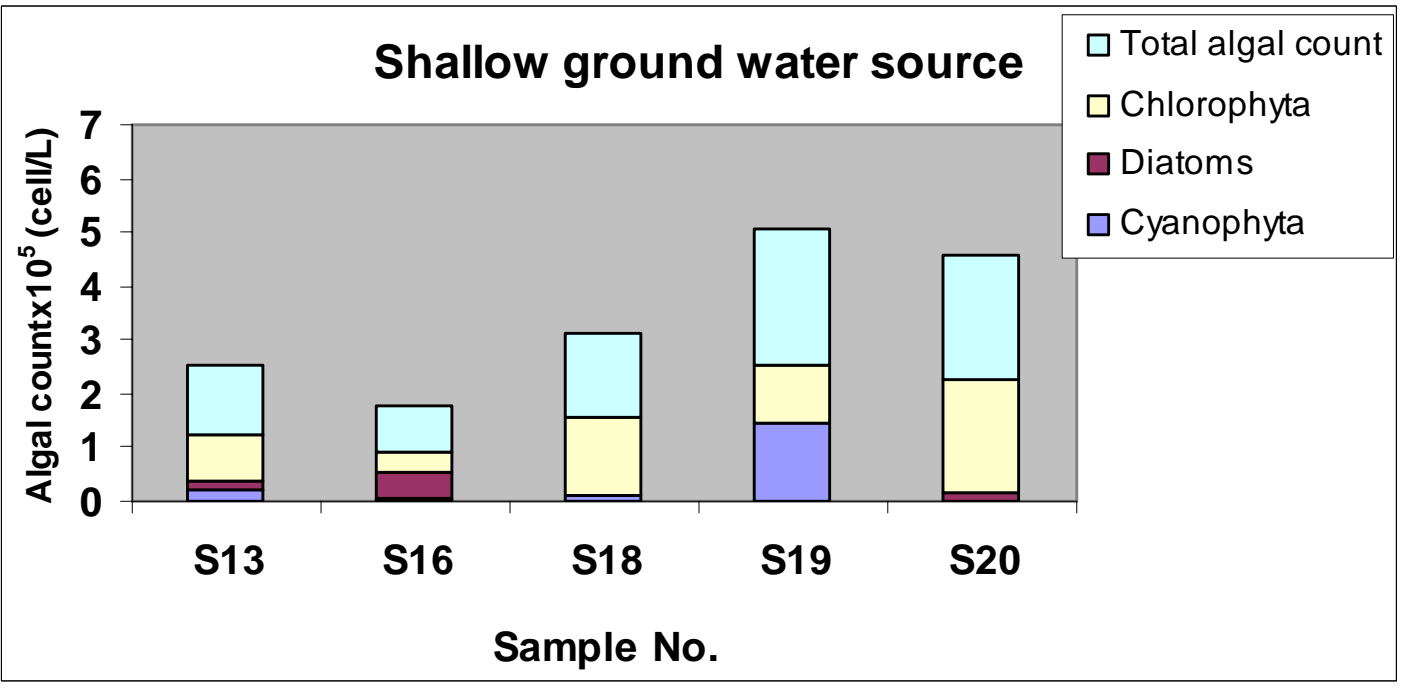

(b)

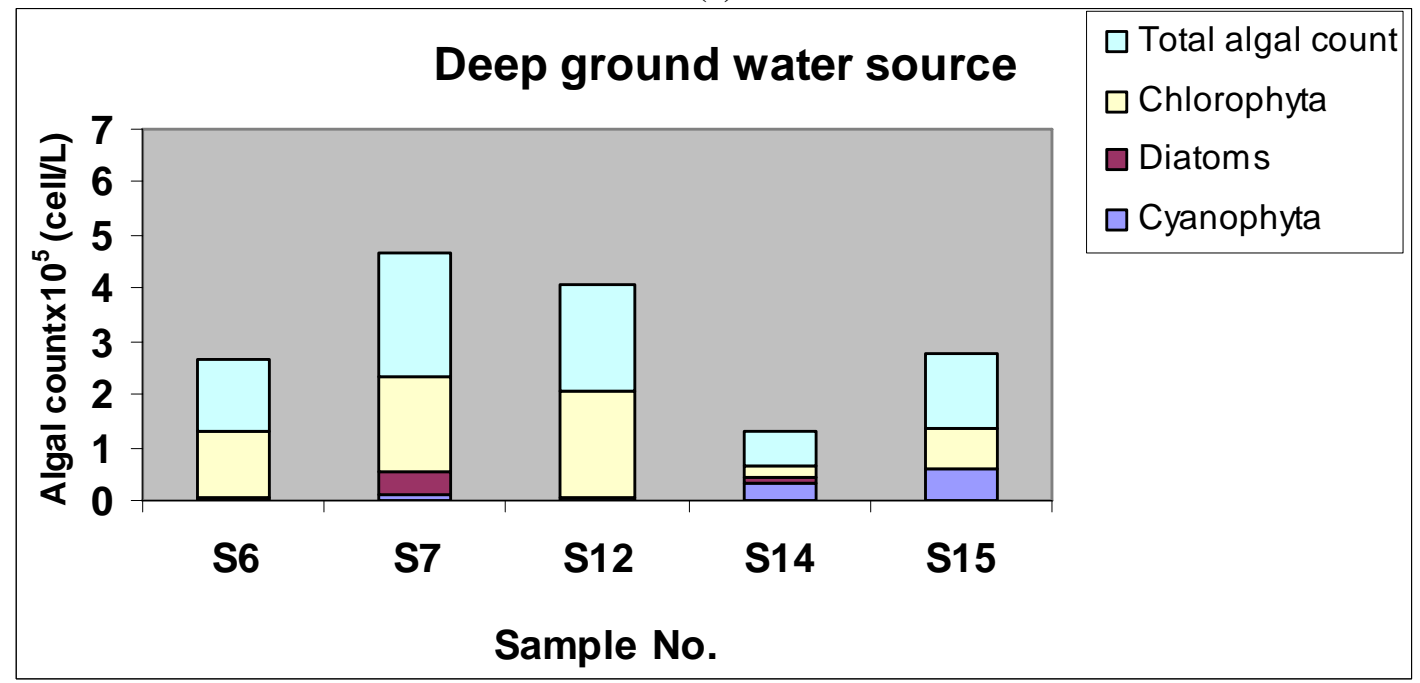

(c)

Fig. 4 Changes in algal groups count in drinking water of different origins. 


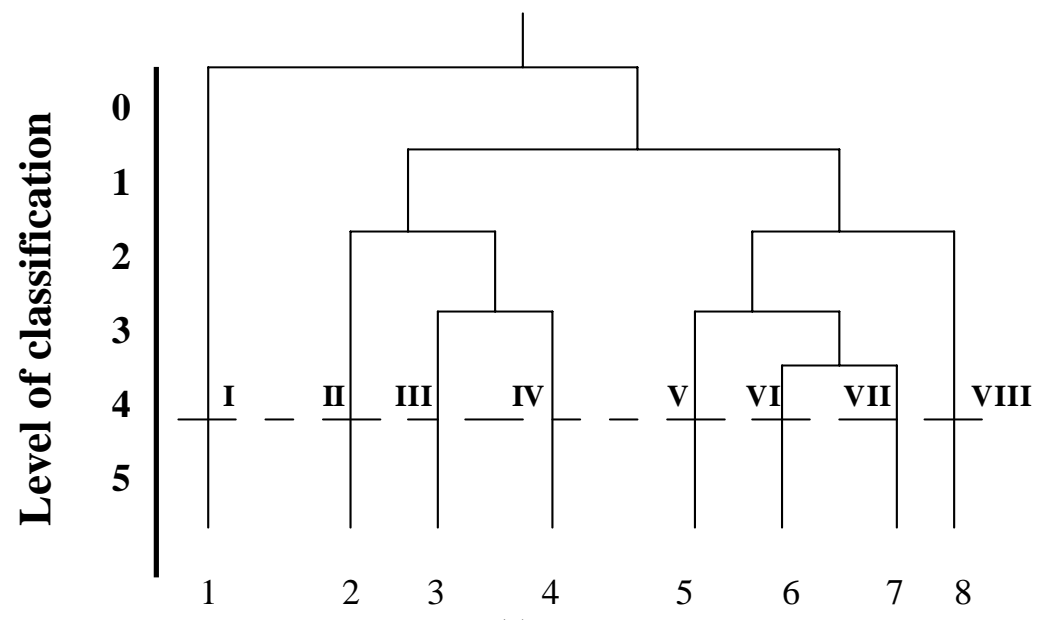

(a)

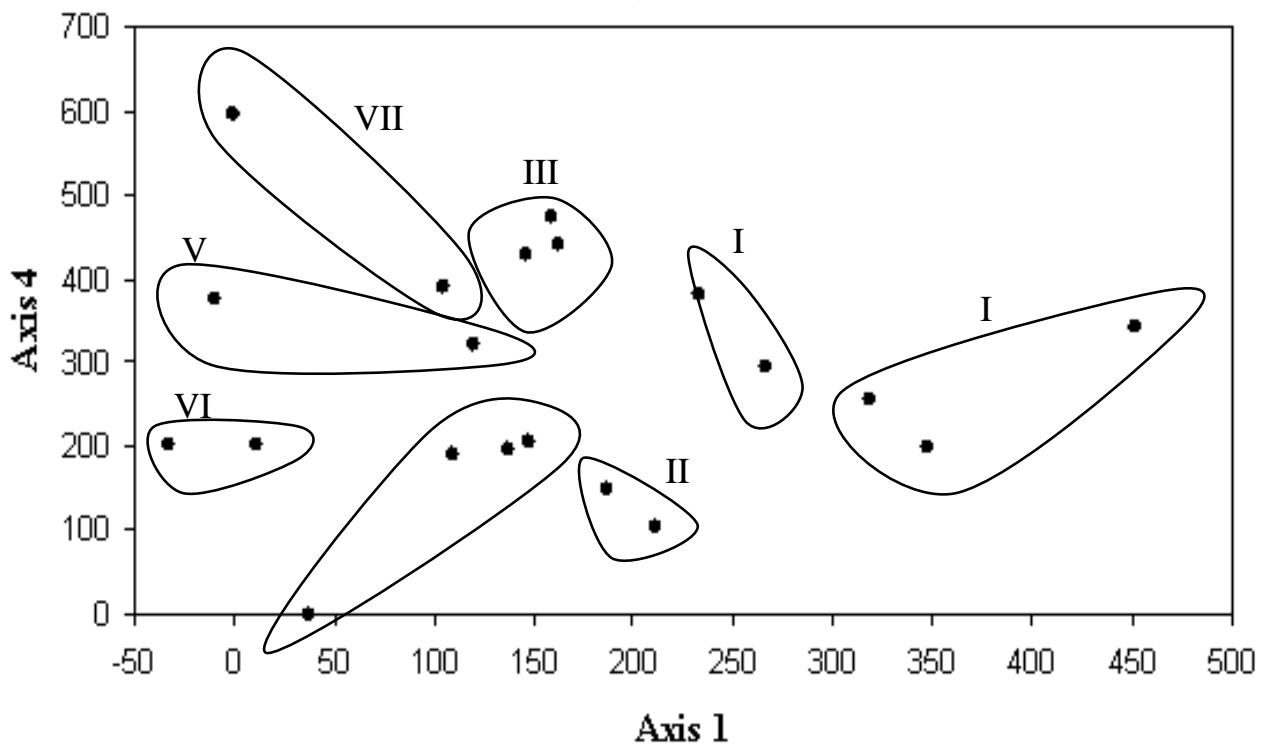

(b)

Fig. 5 Similarity dendrogram between water samples according to the abundance of the phytoplankton groups. (a) Classification (TWINSPAN) and (b) ordination (DECORANA) of the 20 water samples.

Estimated similarities of algal composition among the studied tap water samples using TWINSPAN classification led to the classification of samples into eight groups at level five (Fig. 5a). The segregation among the eight groups along the ordination plane of the first and fourth axes of DECORANA is obvious (Fig. 5b). The eight groups with their dominated alga species are: Group I (samples 1, 2 and 16) with Cyclotella kutzingiana, Syndra acus, Syndra ulna, Nitzchia acicularis, Cyclotella comta and Fragilaria capucina; Group II (samples 14 and 3) with Closterium pronum, Calothrix braunii and Dactylococcopsis rhaphidioides; Group III (samples
11, 5 and 8) with Syndra ulna, Closterium pronum, Actinastrum hantzschii and Dictyosphaerium ehrenbergianum; Group IV (samples 7 and 4) with Calothrix braunii, Syndra ulna, Closterium pronum, Coelastrum reticulatum and Dictyosphaerium ehrenbergianum; Group V (samples 7 and 19) with Actinastrum hantzschii and Dactylococcopsis acicularis; Group VI (samples 10 and 13) with Closterium pronum; Group VII (samples 9, 6, 12 and 15) with Actinastrum hantzschii, Closterium pronum, Coelastrum reticulatum, Dictyosphaerium ehrenbergianum and Dactylococcopsis acicularis; and Group VIII (samples 18 and 20) with Closterium 

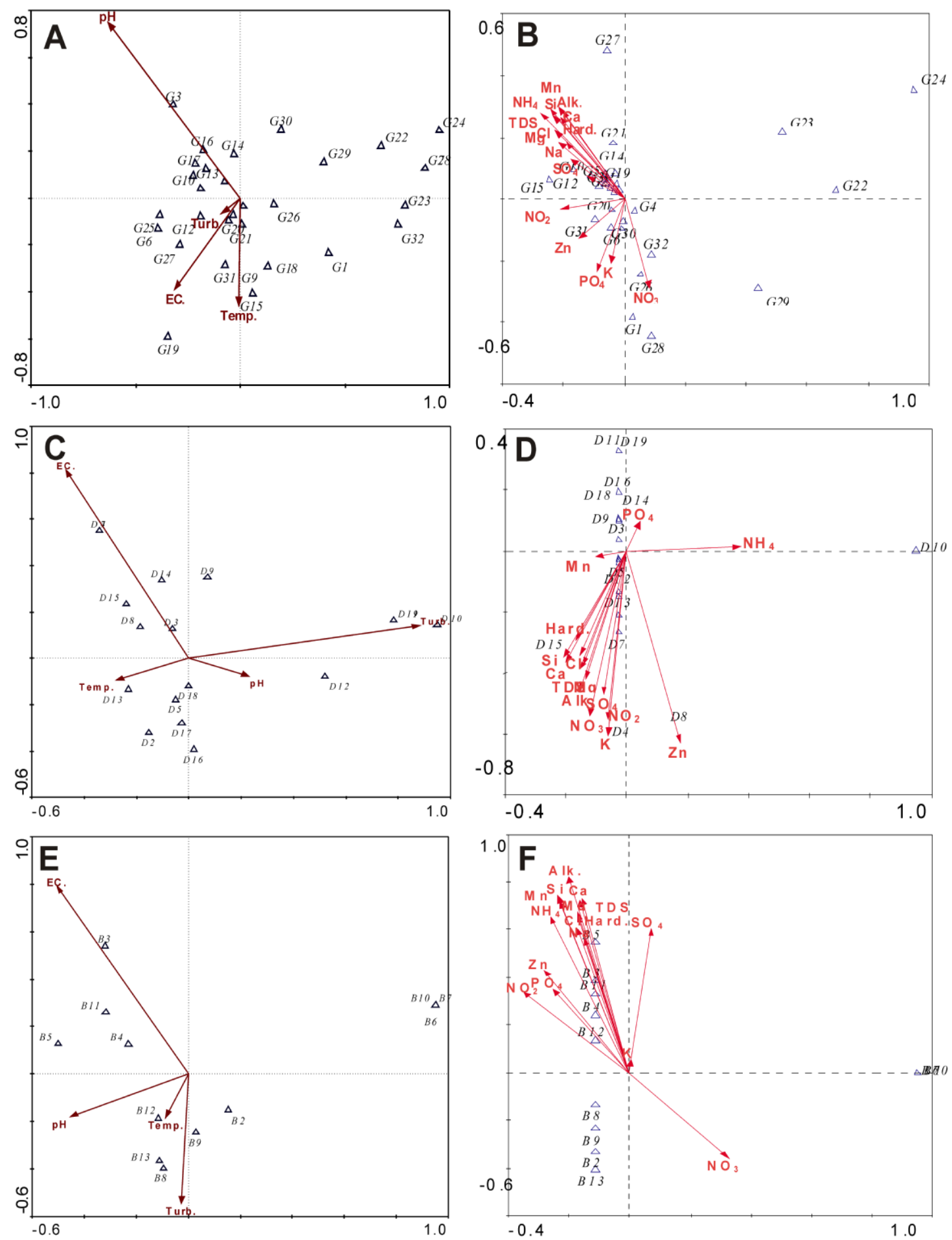

Fig. 6 CCA biplot with physicochemical water parameters (arrows) and the characteristic algal species (points). (A), (C) and (E) Green, diatoms and blue green algae with physical water parameters; and (B), (D) and (F) Green, diatoms and blue green algae with chemical water parameters.

pronum and Actinastrum hantzschii.

Statistical analysis of interrelationships between physico-chemical parameters and algal abundance using CCA correlations were derived (Fig. 6). Abbreviations of algae species which are listed in Table 2 were used. A positive correlation is expressed 
by relatively long vector which roughly pointed into the same direction, whereas arrow pointing into the opposite direction indicates a negative correlation.

For algal abundance with physical parameters, green algae are strongly correlated with $\mathrm{pH}$, diatoms with EC and turbidity and blue green algae with EC. Considering correlation of algal species abundance with physical parameters, the strongest positive correlation is between green algal species of Ankistrodesmus angustus (G3), Kirchneriella contorta (G15) and Staurastrum dejectum (G27) with $\mathrm{pH}$, temperature and EC, respectively; between diatoms species of Fragilaria capucina (D7) with EC, Navicula cryptocephaia (D10) and Syndra vaucheriae (D19) with turbidity; between blue green algae species of Dactylococcopsis acicularis (B3) and Merismopedia elegans (B8) with EC and turbidity, respectively.

For algal abundance with chemical parameters, green algae are strongly correlated with $\mathrm{NH}_{4}$, alkalinity, $\mathrm{Mn}$ and Si, diatoms with $\mathrm{Zn}$, Si and blue green algae with alkalinity. Considering correlation of algal species abundance with chemical parameters, the strongest positive correlation is in green algal species of Oocystis parva (G21). Positive correlation was estimated between abundance of Spirogyra sp. (G26) with $\mathrm{NO}_{3}$, Chodatella armata (G6) with $\mathrm{PO}_{4}$ and $\mathrm{K}$, Ulothrix subtilissima (G31) with $\mathrm{Zn}$, positive correlation between diatoms species of Fragilaria crotonensis (D8) and Surirella ovata (D15) with Zn and $\mathrm{Si}$, respectively, and between blue green algae species of Dactylococcopsis rhaphidioides (B5) with alkalinity, Mn, Si and Ca. In contrast, abundance of other algal species is negatively correlated with the above-mentioned parameters.

\subsection{Bacteriological Analysis}

In general, heterotrophic bacteria are the most predominant in all samples. The highest numbers of bacterial isolates were recovered from samples that are related to deep groundwater source. However, the highest total means of HBC (heterotrophic bacterial count; 80.6 CFU·100 mL ${ }^{-1}$ ) was recorded in samples that are related to shallow groundwater source (Group 2) (Fig. 7). The highest mean TCC (Total Coliform Count), on the other hand, was recorded in samples related to deep ground water origin (25 CFU·100 $\mathrm{mL}^{-1}$ ). Fecal streptococci were detected also in deep

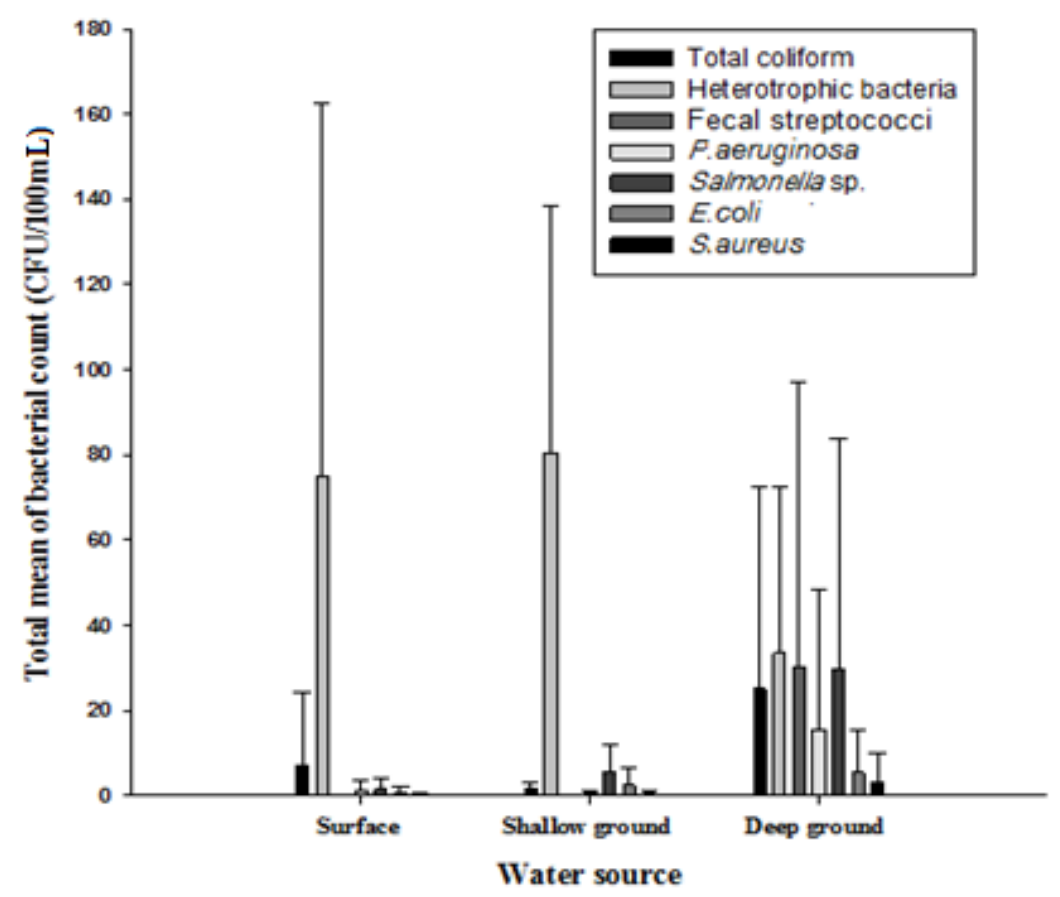

Fig. 7 Total mean bacterial count for different water source. 
Table 3 Bacterial count for the collected water samples.

\begin{tabular}{|c|c|c|c|c|c|c|c|c|}
\hline \multirow[b]{2}{*}{ Water source } & \multirow[b]{2}{*}{ Samples } & \multicolumn{7}{|c|}{ *Bacteria mean count $(\mathrm{CFU} / 100 \mathrm{~mL}) \pm \mathrm{SD}$} \\
\hline & & TC & HB & FS & P. aeruginosa & $\begin{array}{c}\text { Salmonella } \\
\text { sp. }\end{array}$ & E. coli & S. aureus \\
\hline \multirow{10}{*}{ Surface } & 1 & $0.0 \pm 0.0$ & $50 \pm 5.0$ & $0.0 \pm 0.0$ & $6.3 \pm 1.5$ & $0.0 \pm 0.0$ & $0.0 \pm 0.0$ & $0.0 \pm 0.0$ \\
\hline & 2 & $0.0 \pm 0.0$ & $32.3 \pm 2.5$ & $0.0 \pm 0.0$ & $0.0 \pm 0.0$ & $0.0 \pm 0.0$ & $0.0 \pm 0.0$ & $0.0 \pm 0.0$ \\
\hline & 3 & $0.0 \pm 0.0$ & $1.0 \pm 0.0$ & $0.0 \pm 0.0$ & $0.0 \pm 0.0$ & $5.3 \pm 1.5$ & $0.0 \pm 0.0$ & $0.0 \pm 0.0$ \\
\hline & 4 & $0.0 \pm 0.0$ & $50.3 \pm 0.57$ & $0.0 \pm 0.0$ & $6.0 \pm 1.0$ & $0.0 \pm 0.0$ & $0.0 \pm 0.0$ & $0.0 \pm 0.0$ \\
\hline & 5 & $8.3 \pm 0.57$ & $44.0 \pm 1.0$ & $0.0 \pm 0.0$ & $0.0 \pm 0.0$ & $1.0 \pm 0.0$ & $1.0 \pm 0.0$ & $0.0 \pm 0.0$ \\
\hline & 8 & $1.0 \pm 0.0$ & $130.0 \pm 4.0$ & $0.0 \pm 0.0$ & $0.0 \pm 0.0$ & $8.0 \pm 2.0$ & $1.0 \pm 0.0$ & $0.0 \pm 0.0$ \\
\hline & 9 & $1.0 \pm 0.0$ & $90.0 \pm 2.0$ & $0.0 \pm 0.0$ & $0.0 \pm 0.0$ & $1.0 \pm 0.0$ & $1.0 \pm 0.0$ & $1.0 \pm 0.0$ \\
\hline & 10 & $5.3 \pm 1.5$ & $300.0 \pm 20.0$ & $0.0 \pm 0.0$ & $0.0 \pm 0.0$ & $0.0 \pm 0.0$ & $5.3 \pm 0.57$ & $0.0 \pm 0.0$ \\
\hline & 11 & $4.3 \pm 0.57$ & $50.0 \pm 3.0$ & $0.0 \pm 0.0$ & $0.0 \pm 0.0$ & $0.0 \pm 0.0$ & $0.0 \pm 0.0$ & $0.0 \pm 0.0$ \\
\hline & 17 & $0.0 \pm 0.0$ & $4.3 \pm 0.57$ & $0.0 \pm 0.0$ & $0.0 \pm 0.0$ & $0.0 \pm 0.0$ & $0.0 \pm 0.0$ & $0.0 \pm 0.0$ \\
\hline \multirow{5}{*}{$\begin{array}{l}\text { Shallow } \\
\text { ground }\end{array}$} & 13 & $3.3 \pm 1.5$ & $18.0 \pm 2.0$ & $0.0 \pm 0.0$ & $0.0 \pm 0.0$ & $0.0 \pm 0.0$ & $0.0 \pm 0.0$ & $0.0 \pm 0.0$ \\
\hline & 16 & $1.0 \pm 0.0$ & $23.0 \pm 2.0$ & $0.0 \pm 0.0$ & $0.0 \pm 0.0$ & $10.3 \pm 2.5$ & $1.0 \pm 0.0$ & $2.0 \pm 0.0$ \\
\hline & 18 & $0.0 \pm 0.0$ & $112.3 \pm 0.33$ & $0.0 \pm 0.0$ & $1.0 \pm 0.0$ & $14.0 \pm 2.0$ & $10.3 \pm 2.5$ & $0.0 \pm 0.0$ \\
\hline & 19 & $1.0 \pm 0.0$ & $150.0 \pm 4.0$ & $0.0 \pm 0.0$ & $0.0 \pm 0.0$ & $3.3 \pm 0.57$ & $1.0 \pm 0.0$ & $0.0 \pm 0.0$ \\
\hline & 20 & $3.3 \pm 0.57$ & $100.0 \pm 10.0$ & $0.0 \pm 0.0$ & $1.0 \pm 0.0$ & $1.0 \pm 0.0$ & $0.0 \pm 0.0$ & $0.0 \pm 0.0$ \\
\hline \multirow{5}{*}{ Deep ground } & 6 & $1.0 \pm 0.0$ & $15.6 \pm 1.5$ & $0.0 \pm 0.0$ & $0.0 \pm 0.0$ & $1.0 \pm 0.0$ & $0.0 \pm 0.0$ & $0.0 \pm 0.0$ \\
\hline & 7 & $7.0 \pm 2.0$ & $100.0 \pm 10.0$ & $0.0 \pm 0.0$ & $0.0 \pm 0.0$ & $14.6 \pm 2.1$ & $3.3 \pm 0.57$ & $1.0 \pm 0.0$ \\
\hline & 12 & $0.0 \pm 0.0$ & $18.0 \pm 1.0$ & $0.0 \pm 0.0$ & $1.0 \pm 0.0$ & $0.0 \pm 0.0$ & $0.0 \pm 0.0$ & $0.0 \pm 0.0$ \\
\hline & 14 & $7.3 \pm 0.57$ & $33.0 \pm 2.0$ & $0.0 \pm 0.0$ & $1.0 \pm 0.0$ & $6.0 \pm 2.0$ & $1.0 \pm 0.0$ & $0.0 \pm 0.0$ \\
\hline & 15 & $110.0 \pm 5.0$ & $1.0 \pm 0.0$ & $150.0 \pm 5.0$ & $75.0 \pm 5.0$ & $126.0 \pm 2.0$ & $23.0 \pm 3.0$ & $15.0 \pm 2.0$ \\
\hline
\end{tabular}

*TC: total coliform; HB: heterotrophic bacteria; FS: fecal streptococci; SD: standard deviation.

groundwater source-related samples with values up to $150 \mathrm{CFU} \cdot 100 \mathrm{~mL}^{-1}$ while they were not recovered from both surface and shallow groundwater source samples.

Bacterial count for all water samples were compared with the WHO [12] guideline value (Table 3). TC counts for all samples were within the WHO guideline value $\left(0 \mathrm{CFU} \cdot 100 \mathrm{~mL}^{-1}\right.$ ) except five samples collected from surface water, and eight samples, four collected from shallow ground and four collected from deep ground samples, respectively. For fecal streptcocci count, the lowest incidence in all samples are below the WHO permissible limits (0 CFU·100 $\mathrm{mL}^{-1}$ ), except sample 15 in deep ground water sample where it has $150.0 \pm 5.0 \mathrm{CFU} \cdot 100 \mathrm{~mL}^{-1}$. Whereas, $P$. aeruginosa counts were within WHO limit (0 CFU.100 mL ${ }^{-1}$ ), except water samples No. 1 and No. 4 which collected from surface, samples No. 18 and No. 20 from shallow ground and samples No. 12, No. 14 and No. 15 from deep ground water. Moreover,
Salmonella sp. counts were within WHO limit (0 CFU.100 $\mathrm{mL}^{-1}$ ), except surface water samples 3, 5, 8 and 9. For shallow and deep ground water samples, they exceed WHO limit except sample 13 and 12 for shallow and deep ground water, respectively. In addition as represented in Table 3, four samples only exceed WHO limit for $S$. aureus and E. coli. While, all HB were within WHO guideline value (500 CFU·100 $\left.\mathrm{mL}^{-1}\right)$.

Analysis of correlation between abundance of bacterial divisions (Table 4) revealed that total coliform bacteria are significantly correlated with Fecal Streptococci., P. aeruginosa, Salmonella sp., E. coli and S. aureus (up to $r=0.992$ ). On the contrary, no correlation was estimated between any of heterotrophic bacteria and the other isolated bacteria.

The CCA for correlation between bacterial count and physicochemical water properties (Fig. 8a and 8b) showed strong correlation between total coliform (B1) and temperature, $\mathrm{NH}_{4}$ and $\mathrm{PO}_{4}$, E. coli (B6) and EC, 
Table 4 Correlation analysis among bacteria.

\begin{tabular}{|c|c|c|c|c|c|c|c|}
\hline & Total coliform & $\begin{array}{l}\text { Heterotrophic } \\
\text { bacteria }\end{array}$ & $\begin{array}{l}\text { Fecal } \\
\text { streptococci }\end{array}$ & P. aeruginosa & Salmonella sp. & E. coli & S. aureus \\
\hline Total coliform & 1 & & & & & & \\
\hline Heterotrophic bacteria & 0.135 & 1 & & & & & \\
\hline Fecal streptococci & $0.893^{* *}$ & -0.213 & 1 & & & & \\
\hline P. aeruginosa & $0.882^{* *}$ & -0.221 & $0.992^{* *}$ & 1 & & & \\
\hline Salmonella sp. & $0.874^{* *}$ & -0.194 & $0.988^{* *}$ & $0.980^{* *}$ & 1 & & \\
\hline E. coli & $0.856^{* *}$ & 0.022 & $0.892^{* *}$ & $0.891^{* *}$ & $0.922^{* *}$ & 1 & \\
\hline S. aureus & $0.865^{* *}$ & -0.215 & $0.979^{* *}$ & $0.959^{* *}$ & $0.976^{* *}$ & $0.865^{* *}$ & 1 \\
\hline
\end{tabular}

** Correlation is significant at the 0.01 level (2-tailed).

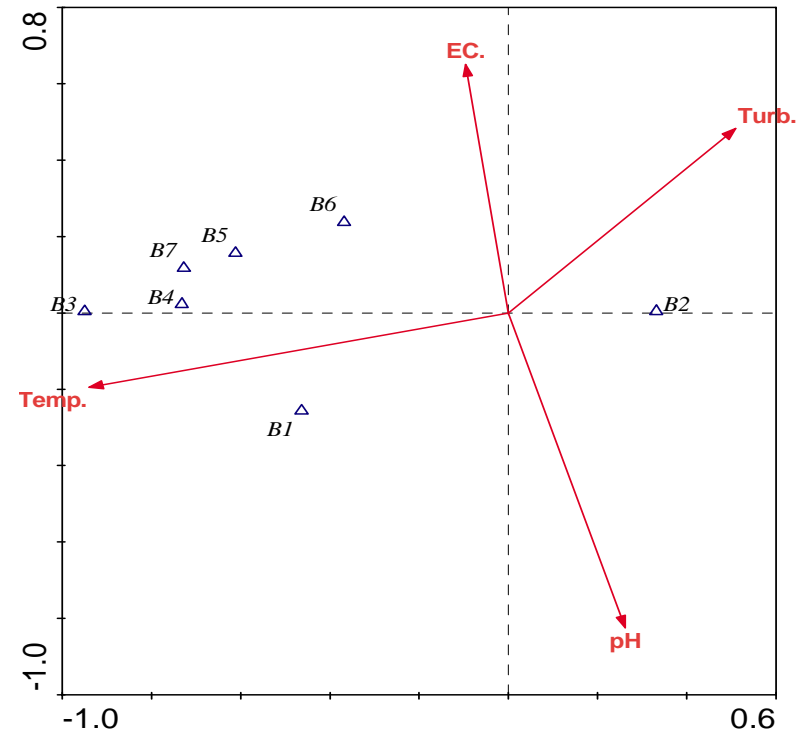

(a)

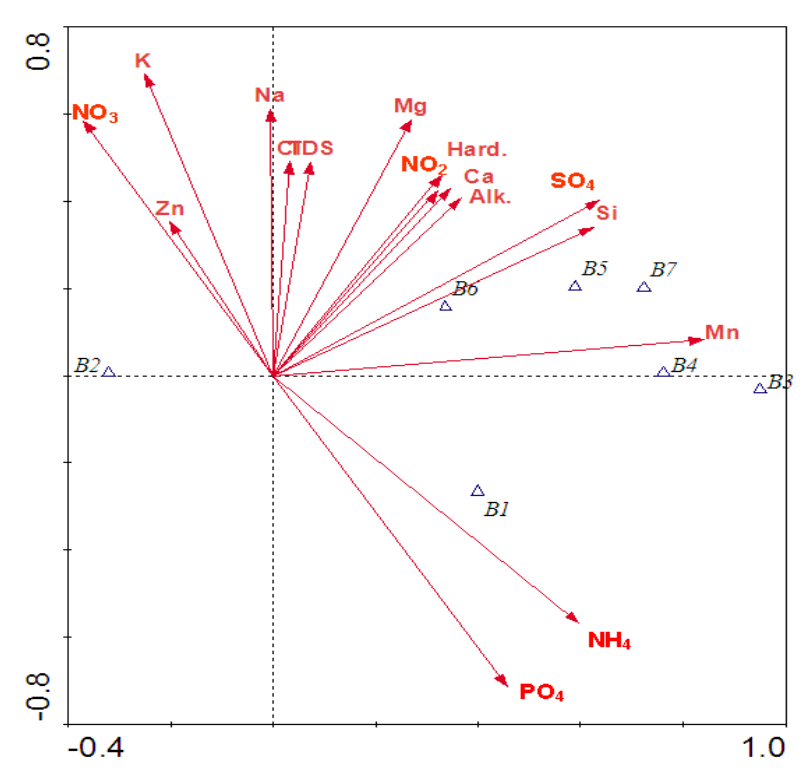

(b)

Fig. 8 Biplot of CCA showing the relationships between bacterial indicators and physicochemical water characteristics. (B1): total coliform bacteria, (B2): heterotrophic bacteria, (B3): fecal streptococci, (B4): $P$. aeruginosa, (B5): Salmonella sp., (B6): E. coli, (B7): S. aureus. (a) Physical water properties; (b) chemical water properties.

heterotrophic bacteria (B2) and turbidity, and $\mathrm{NO}_{3}$, Salmonella sp. (B5) and $\mathrm{Si}$ and $\mathrm{SO}_{4}$, Pseudomonas aeruginosa (B4) and $\mathrm{Mn}$. In contrast, abundance of other bacterial species is negatively correlated with physicochemical properties of drinking water samples.

\section{Discussion}

Safety of the drinking water in developed countries is usually accomplished through a planned monitoring activity. Absolute water safety is, however, impossible to achieve on account of both the numberless chemical and microbiological hazards potentially entering the water chain and the high intrinsic vulnerability of water to accidental or deliberate contamination [32].
The analysis of the obtained results shows distinctive heterogeneity of physicochemical and biological properties among the studied tap water samples. This refers to both inadequate treatment in water plants, hence, the influence of water source, or post treatment contamination in distribution pipes. Physico-chemical properties of the studied samples in general are below the WHO [12] limits except for TDS, manganese and iron concentrations in some samples related mainly to the shallow ground waters. Nitrate also shows higher values compared to the original groundwater. These two phenomenons reflect the bad management for the purification and transportation processes. Soil water rich in sewage 
water may infiltrate into the pipe lines during the low flow rate causing water pollution.

Drinking water should contain no algae. Distinctive relationships between abundance of algal groups and the proposed source of water in most studied samples (Fig. 4) argue for the role of source of water in shaping algae in tap water of Tanta City. This assumes that treatment of water in plant was not $100 \%$ effective in removing algae [33]. Since algae can travel all the way from origin to the end point, the levels detected in tap water are exclusively from algae, not removed by treatment [6]. Some algae could proliferate or survive in the system in the dark, using the ability of some genera to develop mixotrophic and/or heterotrophic metabolism (extensively reviewed by Neilson, Lewin [34]). These microscopic algae, having a relatively active role, could become members of the normal flora of drinking water systems [6]. In this case, it is logical to consider the possibility of algae regrowth, probably into the biofilms. Thus, biofilms in drinking water systems can serve as an environmental reservoir for pathogenic microorganisms and represent a potential source of water contamination, resulting in a potential health risk for humans if left unnoticed [18].

For regulating the microbial quality of investigated drinking-water, the high HPC is indicative of the presence of high organic and dissolved salts in the water. This is consistent with the strong correlation between the HPC with the turbidity, $\mathrm{K}, \mathrm{Al}, \mathrm{Cu}$ and $\mathrm{Sn}$, as estimated by CCA. High TCC above the WHO [11] guideline values points to fecal contamination [35, 36] of tap water in Tanta City. According to EPA [36], every water sample that has coliform must be analyzed for either fecal coliforms or E. coli. Significant correlation of total coliform with the number of pathogenic additional bacterial indicators is not in agreement with EPA and WHO standard for recreational use (stated that pathogenic organism must not be present in water) because they are of public health significance, having been associated with gastrointestinal infections [37, 38]. Many authors have reported waterborne disease outbreaks in water meeting the coliform regulations [39]. The detection of pathogenic enteric bacteria also reveals the alarming situation for water borne epidemics in Tanta city. The general trend of tap water of proposed mixed origin to contain the highest number of the isolated bacteria concludes that treatment against microbes in water plants was not highly effective. In addition, microbes can enter water utility distribution systems and biofilm formation may account for the persistence of microbes in the distribution systems [40]. The walls of the pipes in the distribution system provide ideal surfaces for microbial colonization [41].

\section{Conclusion}

Physicochemical and biological (algal and bacterial) characterization of drinking water from Tanta City, based on 20 tap water samples collected during December, 2011 covering all water plants and the areal extension of the pipe line network in Tanta City, reports the following: (1) Fe, Mn and hardness in some samples of groundwater origin are obviously exceeding the WHO limit; (2) sixty three species of green algae, diatoms and blue-green algae that may cause unpotable taste and odor, and the samples of surface origin are the most containing for green algae; and (3) $50 \%$ of samples of surface origin, $80 \%$ of samples of both deep and shallow groundwater origins crossed WHO and Egyptian guideline in their containing total coliform count. This concludes that the treatment processes in water plants in Tanta City were not $100 \%$ effective. In addition, drinking water pipes can serve as an environmental reservoir for pathogenic microorganisms and represent a potential source of water contamination resulting in a potential health risk for humans if left unnoticed. Thus, domestic water sanitation and disinfection programs must be involved by the drinking water authority of Tanta City. 


\section{Acknowledgments}

The Research Project Funds, Tanta University, financially supported this study. Authors are grateful to Dr Mohamed Hamdy (Geology Department, Tanta University) for his help in the sampling and revising the draft of the manuscript. Thanks also go to Dr. Dalia Ahmed (Botany Department, Tanta University) for her help in statistical analysis. Thanks to Anonymous reviewers for their remarks.

\section{References}

[1] A. Yassi, T. Kjellström, T. De Kok, T. Guidotti, Basic Environmental Health, Oxford University Press, New York, 2001.

[2] J. Adejuwon, C.J. Mbuk, Biological and physiochemical properties of shallow wells in Ikorodu town, Lagos Nigeria, Journal of Geology Mining Research 3 (2011) 161-168.

[3] A.L. Ihekoronye, P.O. Ngoddy, Integrated Food Science and Technology for the Tropics, Macmillan Press London, Oxford, 1985, pp. 95-195.

[4] Guidelines for Drinking Water Quality, 2nd ed., Vol. 2, WHO (World Health Organization), Geneva, 1996.

[5] K. Emde, G.R. Finch, Detection and occurrence of waterborne bacterial and viral pathogens, Research Journal WPCF 63 (1991) 730-734.

[6] F. Codony, A.M. Miranda, J. Mas, Persistence and proliferation of some unicellular algae in drinking water systems as result of their heterotrophic metabolism, Water SA Journal 29 (1) (2003) 113-116.

[7] D.E. Ledra, C.H. Prosperi, Water mutagenicity and toxicological in Rio Tercero (Cordoba, Argentina), Water Research Journal 30 (4) (1996) 819-824.

[8] K. Sivonen, Cyanobacterial toxins and toxins production, Phycologia Journal 35 (6) (1996) 12-24.

[9] J.B. Rose, R.M. Atlas, C.P. Gerba, J.R. Gilchristm, M.W. Lechevallier, M.D. Sobsey, et al., Microbial pollutants in our nation's water, Environmental and Public Health Issues, American Society for Microbiology, American, 1999.

[10] S.A Shehata, G.H. Ali, S.Z. Wahba, Distribution pattern of Nile Water algae with reference to its treatability in drinking water, Journal of Applied Science Research 4 (6) (2008) 722-730.

[11] P. Payment, M. Waite, A. Dufour, Introducing parameters for the assessment of drinking water quality, in: Assessing Microbial Safety of Drinking Water; Improving Approaches and Methods, OECD, WHO, 2003, pp. 47-77.
[12] Guidelines for Drinking-Water Quality 4th ed., WHO (World Health Organization), Geneva, 2011.

[13] J. Wingender, Hygienically relevant microorganisms in biofilms of man-made water systems, in: H.C. Flemming, J. Wingender, U. Szewzyk (Eds.), Biofilm Perspectives, Springer International, Heidelberg, New York, 2011.

[14] M.W. Lechevallier, N.J. Welch, D.B. Smith, Full-scale studies of factors related to coliform regrowth in drinking water, Applied and Environmental Microbiology 62 (1996) 2201-2211.

[15] I. Sundh, C. Mikkeia, M. Nilsson, B. Svensson, Potential methane oxidation in a sphagnum peat bog: Relation to water table level and vegetation type, in: Proceedings of the 9th International Peat Congress, Uppsala, Sweden, 1992, pp. 142-151.

[16] E.E. Geldreich, Microbial Quality of Water Supply in Distribution Systems, CRC Press, Boca Raton, FL, 1996.

[17] J. Wingender, H.C. Flemming, Biofilms in drinking water and their role as reservoir for pathogens, International Journal of Hygiene and Environmental Health 214 (6) (2011) 417-423.

[18] J. Leflaive, L. Ten-Hage, Algal and cyanobacterial secondary metabolites in freshwaters: A comparison of allelopathic compounds and toxins, Freshwater Biology 52 (2007) 199-214.

[19] Anonymous, Resource and Ecological Assessment of San Pedro Bay, Philippines, Technical Report for Fishery Sector Program, U.P. Visayas Foundation, Inc. and IMFO (Institute of Marine Fisheries and Oceanography), 1996.

[20] H. Ültermohle, Quantitative methods zur untersuchugn des Nannoplanktons, in: Abberhalden, Handbuck der Biologischen, Arbietsmethoden, Berlin 2 (1936) 1879-1937.

[21] A. Prescott, The algae, A review, New York, 1969.

[22] L.A. Whitford, G.J. Schumacher, A Manual of Fresh-Water Algae, Sparks Press, Raleigh N.C., 1973.

[23] W.M. Ingram, C.M. Palmer, Simplified procedures for collecting, examining, and recording plankton in water, Journal American Water Works Association 44 (1952) 617.

[24] E.W. Rice, M.J. Allen, K.P. Brenner, S.C. Edberg, Assay for b-D-glucuronidase in species of the genus E. coli and its applications for drinking-water analysis, Applied and Environmental Microbiology 57 (1991) 592-593.

[25] Standard Methods for the Examination of Water and Wastewater, 20th ed., APHA (American Public Health Association), Washington, DC, 1998.

[26] Microbiological Examination of Water, in: Standard Methods Evaluation of Water one Wastewater, 18th ed., APHA (American Public Health Association), Washington, DC, 1992.

[27] B. Balogun, Monitoring and Assessing Drinking Water Quality 2000, Lagos State Water Corporation In-House 
Training for Chemist, 2000.

[28] D.J. Brenner, N.R. Krieg, J.T. Staley, G.M. Garrity, Bergey's Manual of Systematic Bacteriology 2nd ed., Vol. 2, Part (A), The Proteobacteria, Introductory Essays, New York, Springer, 2005.

[29] M.O. Hill, Decorana-A Fortran Program for Detrended Correspondence Analysis and Reciprocal Averaging, Cornell University, Ithaca, N.Y., 1979.

[30] M.O. Hill, Twinspan-A Fortran Program for Arranging Multivariate Data in an Ordered Two-Way Table by Classification of the Individuals and Attributes, Cornell University, Ithaca, N.Y., 1979.

[31] C.J.F. ter Braak, The analysis of vegetation-environment relationships by CCA (canonical correspondence analysis), Vegetatio Journal 69 (1987) 69-77.

[32] E. Ferretti, L. Lucentini, E. Veschetti, L. Bonadonna, A. Stammati, L. Turco, et al., Screening and identification of unknown contaminants in water destined to human consumption: A case study, Micro Chemistry Journal 85 (2007) 57-64.

[33] M.C. Steynberg, K. Adam, A.J.H. Pieterse, An algal monitoring protocol: The strategic link between reservoir and treatment process, Water Science Technology Journal 37 (1998) 153-159.

[34] A.H. Neilson, R.A. Lewin, The uptake and utilization of organic carbon by algae: An essay in comparative biochemistry, Phycologia 13 (1974) 227-264.
[35] M.I. Osuinde, N.R. Eneuzie, Bacteriological analysis of ground water, Nigeria Journal of Microbiology 13 (1999) 47-54.

[36] US Environmental Protection Agency Safe Drinking Water, Act. EPA 816-F-03-016, 2003.

[37] D.J. Donald, T. Yi-Chen, T. Miao-Chi, H. Mei-Man, L. Yu-Lan, C.C. Lien-Ching, et al., Investigation of a collective diarrhea outbreak among cadets of a certain training unit located in Neipu Township, Pingtung County, Epidemiology Bulletin 25 (2006) 269-279.

[38] A.J.R. Hinton, R. Holser, Role of water hardness in rinsing bacteria from the skin of processed broiler chickens, Journal of International Poultry Science 2 (2009) 112-115.

[39] L. Gofti, D. Zmirou, F.S. Murandi, P. Hartemann, J.I. Poleton, Waterborne microbiological risk assessment: A state of the art and perspectives, Review Epidemiology, Sante' Publi. 47 (1999) 61-75.

[40] F. Marciano-Cabral, M. Jamerson, E.S. Kaneshiro, Free-living amoebae, legionella and mycobacterium in tap water supplied by a municipal drinking water utility in the USA, Journal of Water and Health 8 (1) (2010) 71-82.

[41] H.C. Flemming, Microbial biofouling-Unsolved problems, insufficient approaches and possible solutions, in: H.C. Flemming, J. Wingender, U. Szewzyk (Eds.), Biofilm Perspectives, Springer International, Heidelberg, New York, 2011, (Chapter 5). 